\title{
On identifying Palaeolithic single occupation episodes: archaeostratigraphic and technological approaches to the Neanderthal lithic record of stratigraphic unit xa of El Salt (Alcoi, eastern Iberia)
}

\author{
Alejandro Mayor ${ }^{1,2} \cdot$ Cristo M. Hernández ${ }^{1,3}$. Jorge Machado ${ }^{1}$ - Carolina Mallol ${ }^{1,4,5}$ • Bertila Galván ${ }^{1,5}$
}

Received: 31 July 2019 / Accepted: 22 January 2020

(C) Springer-Verlag GmbH Germany, part of Springer Nature 2020

\begin{abstract}
Within the framework of archaeological palimpsest dissection, stratigraphic association of lithic remains with hearths and other archaeological materials in undisturbed Neanderthal contexts allows us to seek patterns in lithic and faunal assemblage composition, assess the degree of time averaging within assemblages and investigate the spatial distribution of archaeological remains. So far, the European Neanderthal record shows variability in such spatial parameters, not only among different geographic regions but also across time. This approach has been employed to draw conclusions about the main features of Neanderthal occupations from in situ archaeological contexts within individual site sequences. As contribution to this topic, we present new results from our ongoing archaeostratigraphic investigation of stratigraphic unit xa from El Salt (Alcoi, Alacant, eastern Iberia). Our previous study, based on stratigraphic analysis of the lithic record consisting of raw material units, yielded several micropalimpsests within unit xa. Here, we carry out further technological and spatial analysis of the micropalimpsest units. The results obtained from it suggest that we may be able, in specific cases, to recognise indicators of diachrony within the context of these archaeostratigraphic units. This confirms the existence of a micropalimpsest, and suggests that we have the chance to find analytical frames that are even closer to the human temporal scale than the AU. This should be the target of future interdisciplinary behavioural study of El Salt unit xa. This work illustrates the potential of a spatial and archaeostratigraphic approach to stone tool technology and brings to light the importance of archaeological palimpsest dissection as a first step for behavioural analysis in Palaeolithic research.
\end{abstract}

Keywords Middle Palaeolithic $\cdot$ Neanderthals $\cdot$ Palimpsest dissection $\cdot$ Archaeostratigraphy $\cdot$ Raw material unit $\cdot$ El Salt

This paper is a part of his $\mathrm{PhD}$ thesis and all authors agree.

This article is part of the Topical Collection on Is 'Neanderthal behaviour' a useful concept?

Alejandro Mayor

alejandro.mayor@ua.es

1 Grupo de Investigación Sociedades Cazadoras-Recolectoras Paleolíticas; Departamento de Geografía e Historia; Facultad de Humanidades, Universidad de La Laguna, Guajara campus, 38071 San Cristóbal de la Laguna, Santa Cruz de Tenerife, Spain

2 Àrea de Coneixement de Prehistòria; Departament de Prehistòria, Arqueologia, Història Antiga, Filologia Llatina i Filologia Grega; Facultat de Filosofia i Lletres, Universitat d'Alacant, Sant Vicent del Raspeig campus, 03690 Sant Vicent del Raspeig, Alacant, Spain
3 Área de Didáctica de las Ciencias Sociales; Departamento de Didácticas Específicas; Facultad de Educación, Universidad de La Laguna, Edificio Central campus, 38200 San Cristóbal de la Laguna, Santa Cruz de Tenerife, Spain

4 Archaeological Micromorphology and Biomarker Research Laboratory; Instituto Universitario de Bio-Orgánica Antonio González, Universidad de La Laguna, Anchieta campus, 38296 San Cristóbal de la Laguna, Santa Cruz de Tenerife, Spain

5 Área de Conocimiento de Prehistoria; Unidad de Docencia e Investigación de Prehistoria, Arqueología e Historia Antigua; Departamento de Geografía e Historia; Facultad de Humanidades, Universidad de La Laguna, Guajara campus, 38071 San Cristóbal de la Laguna, Santa Cruz de Tenerife, Spain 


\section{Introduction}

The palimpsest problem and the consequent aim of identifying indicators of diachrony within the archaeological record have become central issues in Middle Palaeolithic research (cf. Mallol and Hernández 2016). This is because approaching the interpretative boundaries of human behaviours through the archaeological record implies the definition of analytical units that permit us to explore the "ethnographic" or human time-scale as closely as possible (contra Reeves et al. 2019).

As a first step, site formation and taphonomic processes affecting the assemblages are the most significant methodological factors for distinguishing between the human and the geological temporal scales (e.g. Albert et al. 2012; Gabucio et al. 2016; Goldberg and Berna 2010; Henry 2012; Mallol et al. 2012, 2013a; Martínez et al. 2016; Polo et al. 2016; Spagnolo et al. 2016; Tsatskin and Zaidner 2014; Vallverdú 2013a, b; Vallverdú and Courty 2012). Discerning between natural post-depositional sedimentary processes and anthropogenic actions requires a high-resolution methodology. This has been extensively highlighted in previous works, as well as the need for analytical frameworks that allow us to approach Palaeolithic human behaviours at the highest possible temporal resolution (e.g. Audouze and Enloe 1997; Henry 2012; Machado et al. 2015; Mallol and Mentzer 2015; Martínez et al. 2016; Modolo and Rosell 2016; Romagnoli et al. 2018; Rosell et al. 2012a, b; Shott 2008; Vaquero 2013; Vaquero et al. 2012a, b; contra Holdaway and Wandsnider 2006, 2008; Holdaway et al. 2008; Wandsnider 2008). In recent years, a number of different proxies have been employed to improve the temporal resolution of archaeological analyses relating to past human behaviours (e.g. Carrancho et al. 2016; Leierer et al. 2019; Machado and Pérez 2016; Machado et al. 2013, 2017; Pérez et al. 2019; Vidal 2017).
A key tenet emerging from these works is the centrality of interdisciplinary research, which is increasingly necessary to understand both natural and anthropogenic depositional formation processes.

Within this multianalytical framework, the study of the lithic record is critical in the endeavour to comprehend the so-called Palaeolithic human behaviour. Various perspectives from which we can observe anthropogenic lithic record formation processes have allowed us to interpret several behavioural patterns in archaeological contexts. Such behavioural indicators include the recycling or leverage of previously in-site deposited raw materials (e.g. Cuartero et al. 2015; Thiébaut et al. 2010; Vaquero 2011; Vaquero et al. 2015; Zaidner and Grosman 2015), the catchment and management of local lithic resources (e.g. Glauberman 2016; Molina et al. 2010; Ortiz and Baena 2017; Romagnoli et al. 2016; Turq et al. 2017), tool-use and morphopotentiality (e.g. Knutsson et al. 2015; Lazuén and Delagnes 2014; Lemorini et al. 2016; Rots 2015a, b; Val et al. 2017) and technical variability within lithic assemblages (e.g. Baena et al. 2017, 2018; Bourguignon et al. 2004; Casanova et al. 2008; Galván et al. 2009; Martínez et al. 2010; Romagnoli et al. 2017). However, it is fundamental to identify such patterns and behavioural associations from the lithic record within the context of single occupations, as they represent the minimal expression of Palaeolithic hunter-gatherer activity (e.g. Higham 2013; Hudson and Aoyama 2009; Sullivan 1992) and, therefore, the closest material manifestation of the temporal human scale. Methodologically, this has been approached through spatial analysis by combining archaeostratigraphy and lithic refitting to identify specific knapping sequences and intra-site dynamics (e.g. Bourguignon et al. 2008; López et al. 2017; Machado et al. 2013, 2019; Nerudová and Neruda 2017; Romagnoli and Vaquero 2016; Sañudo et al. 2016; Sumner and Kuman 2014; Takakura 2018; Vaquero 2008; Vaquero et al. 2012b, 2017).
Fig. 1 Graphic scheme of the analysed AUs from SU xa

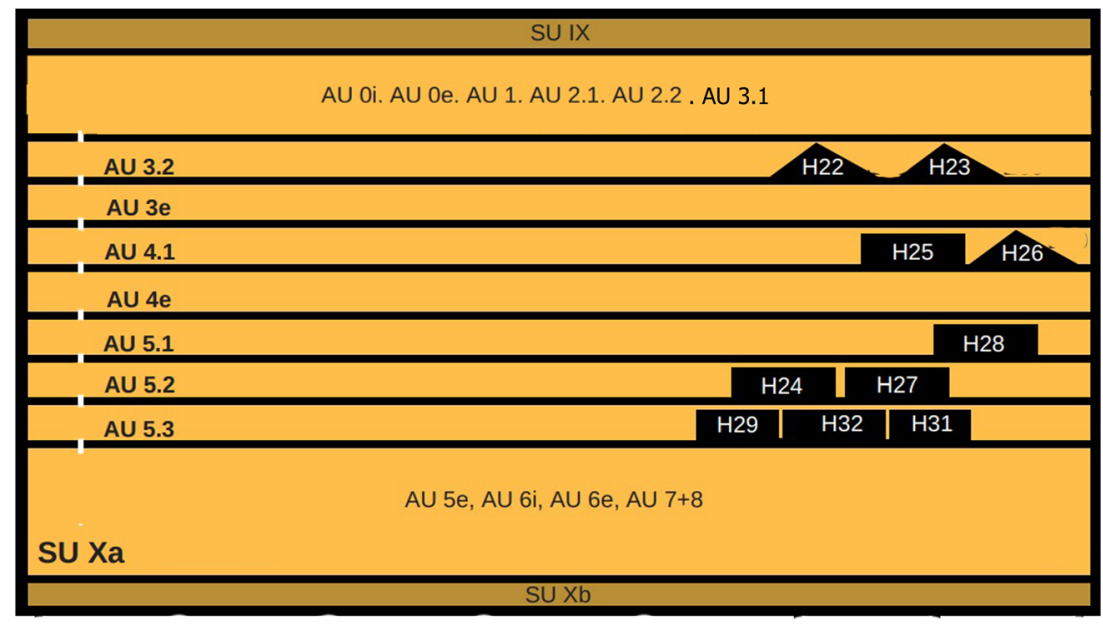

SU Xb = stratigraphic unit · AU $3.2=$ archaeostratigraphic unit $=$ eroded hearth 
Fig. 2 Photogrammetric model of the current state of the archaeological works in El Salt rockshelter (main image). The excavations from the sixties and the Holocene erosion can be noticed as well

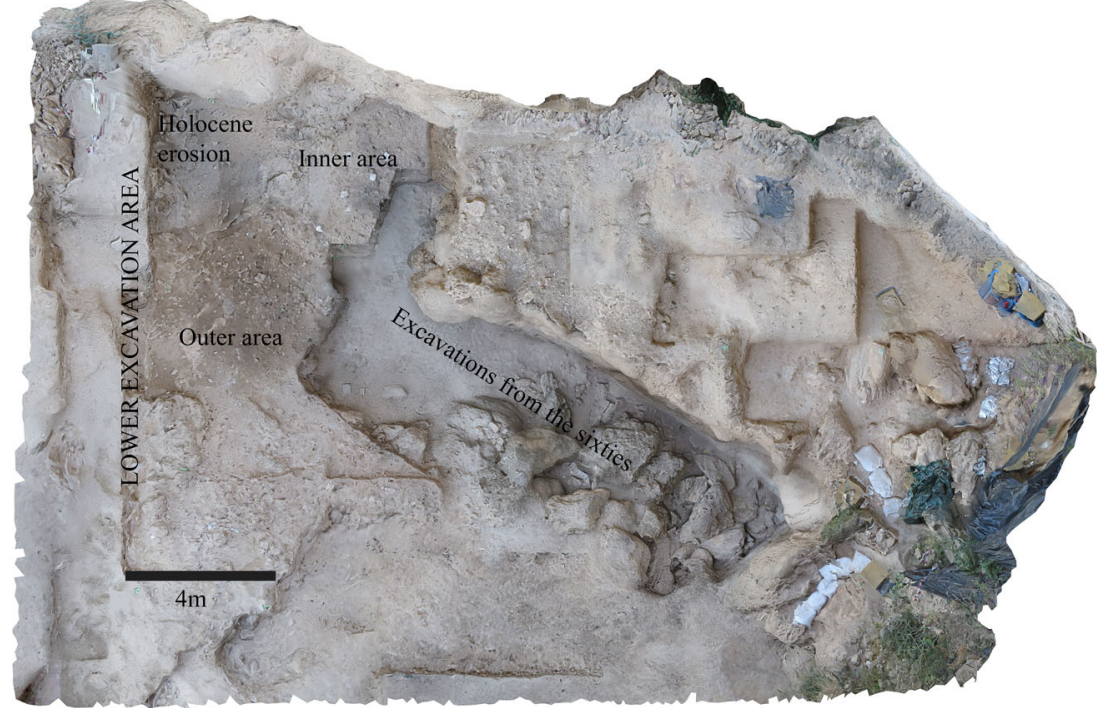

Recent approaches in taxonomic and taphonomic studies carried out on faunal assemblages have also shown their potential in regard to this matter. While traditionally, archaeozoological analysis may help identify seasonal activities and other shorter-term processes, such as animal resource management, or specialised hunting behaviour in a coarse temporal framework (e.g. Gabucio et al. 2014; Rivals et al. 2009a, b, 2014, 2015; Rodríguez et al. 2016; Schoville and Otárola 2014) combining these perspectives with spatial and archaeostratigraphic analysis and bone refitting allow us to considerably narrow down the analytical time-scale (e.g. Chacón et al. 2015; Gabucio et al. 2016; Machado and Pérez 2016; Pérez et al. 2015, 2017; Rosell et al. 2012a, b).

So far, the result of these approaches has been the definition of single beds with archaeostratigraphically correlated anthropogenic material, called archaeostratigraphic units (AUs) obtained from multidisciplinary archaeostratigraphic analysis (cf. Machado et al. 2013). Nevertheless, most AUs still comprise micropalimpsests of diachronic human activity and identification of single occupation episodes remains an elusive goal. This problem has been pointed out by several researchers (e.g. López et al. 2017; Machado et al. 2019; Martínez et al. 2016;
Sañudo et al. 2016; Spagnolo et al. 2016; Vaquero et al. 2012b).

Unraveling these micropalimpsests becomes a fundamental endeavour if we consider single occupation episodes as the most temporally resolved analytical units to characterise Palaeolithic human behaviours. It requires identification of single depositional events and intra-occupational diachrony within the AU. We propose that this can be sought through integrated multiproxy and spatial analysis of the archaeological record and its sedimentary context.

To this end, here we re-examine the lithic record from stratigraphic unit (SU) xa of El Salt, which was previously subdivided into several AUs (cf. Machado et al. 2017) and yielded a limited number of refitting sets. Each of these AUs was interpreted as either a single occupation episode or a micropalimpsest of several occupation episodes close to each other in time (Machado et al. 2017), based on our recognition of indicators of diachrony as inferred from the high amount of potential single inputs of lithic resources, evidence of lithic raw material recycling, post-depositional thermal alterations on lithic and faunal remains, evidence of different faunal processing strategies on a high variability of taxa, superimposed hearths, and the thickness of the sedimentary deposit exceeding what would be expected for a human temporal scale (cf.

Table 1 General quantitative data from the distinct RMUs comprised within each AU

\begin{tabular}{lllll}
\hline AU & Number of RMUs & Number of specimens & Refits & Related hearths \\
\hline 3.2 & 33 & 82 & R1 & H22, H23 \\
4.1 & 13 & 34 & - & H25, H26 \\
5.1 & 8 & 19 & - & H28 \\
5.2 & 9 & 25 & R2, R3 & H24, H27 \\
5.3 & 22 & 56 & R4 & H29, H31, H32 \\
Total & 85 & 216 & 4 & 10 \\
\hline
\end{tabular}




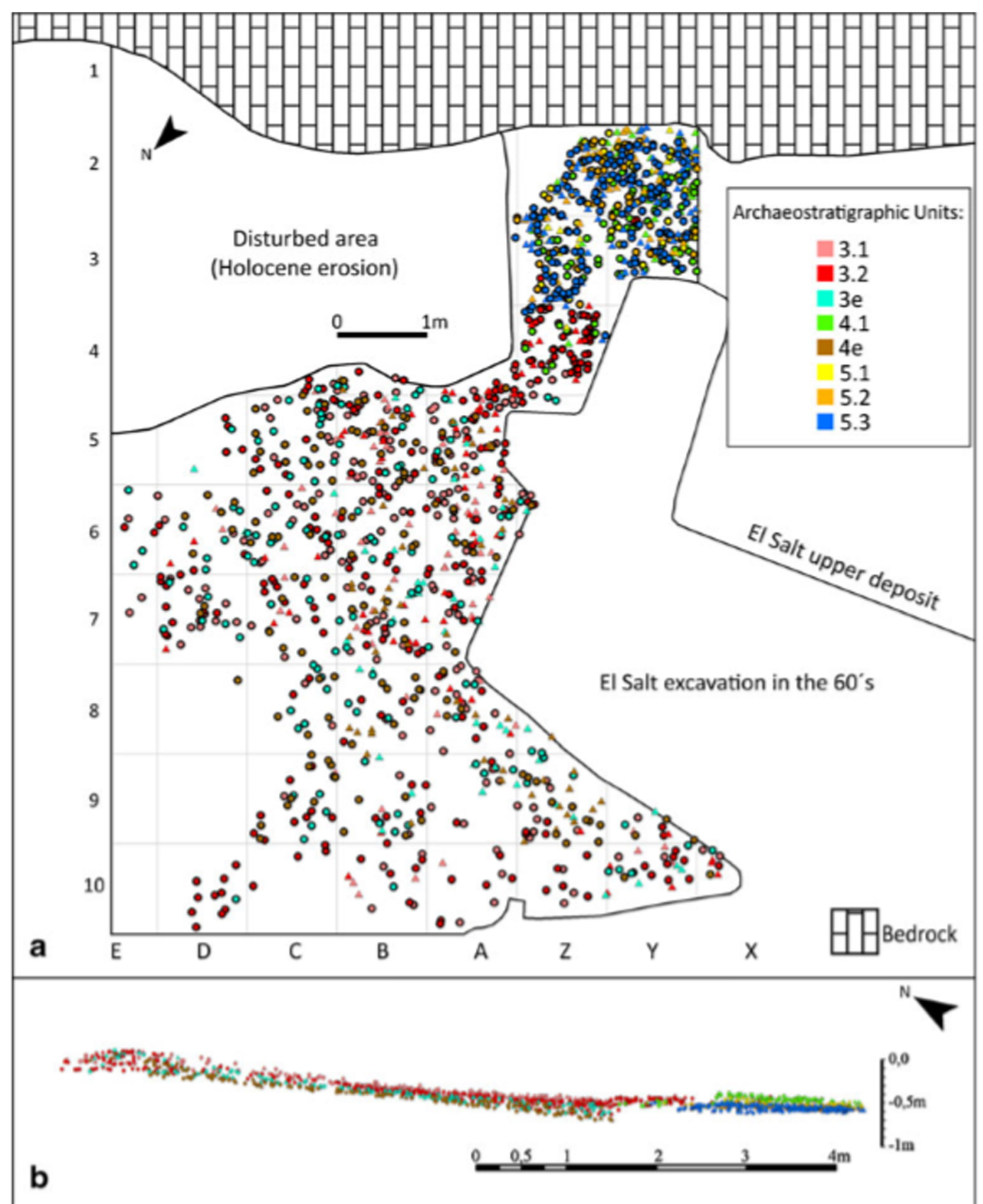

Fig. 3 Spatial distribution horizontally (a) and in-section (b) expressed of the faunal (triangles) and lithic remains (dots) included within the previously defined AUs (Machado et al. 2017)

Galván et al. 2014a; Machado and Pérez 2016; Machado et al. 2017; Mallol et al. 2013b; Pérez et al. 2019).

Here, our goals are to dissect these micropalimpsests and thus to identify frameworks that are closer to the human timescale, so we can characterise technical processes and, therefore, infer technological behaviour within these single occupation episodes.

\section{Materials and methods}

Our previous study was based on the analysis of spatial relationships between faunal, lithic and hearth remains from SU xa (Machado et al. 2017) (Fig. 1), resulting in subdivision of this layer into several AUs. Here, we analyse the lithic record, focusing on the spatial and 
technological analyses of RMUs by AU in search of further temporal markers.

\section{Overview of El Salt and stratigraphic unit xa}

El Salt (Fig. 2) is located at 680 m.a.s.1., on the confluence of Barxell and Polop rivers. Both are tributaries of Serpis river in its upper course, near to the town of Alcoi, in Alacant province. It is at the foot of a $38-\mathrm{m}$ high limestone wall, which is covered by a travertine formation related to the ancient course of Barxell river. In addition, it is placed within the southern foothills of Mariola mountain range. This is a region naturally rich in geological and biotic resources, characterised by a diverse environmental setting, which includes rocky zones, palaeolakes, fluvial valleys, karstic cliffs and springs.

The current archaeological excavations, ongoing since 1986, have exposed a 6.3-m thick stratigraphic sequence comprising twelve SUs (Galván et al. 2014a). SUs I to IV are Holocene deposits and SUs V to XII are Upper Pleistocene containing Middle Palaeolithic remains. Chronometric dating frames the sequence between $60.7 \pm 8.9$ and $45.2 \pm 3.4 \mathrm{ky}$ BP (Galván et al. 2014b).

SU Xa is an archaeologically rich calcareous sandy-silty deposit dated by thermoluminescence to $52.3 \pm 4.6 \mathrm{ky} \mathrm{BP}$ (Galván et al. 2014b). It has been excavated over a $36-\mathrm{m}^{2}$ area. The presence of a wide number of well-preserved combustion structures and minor post-depositional alteration makes this layer an ideal framework to seek single occupations.

\section{Lithic analysis}

Our technological analyses are based on the RMU concept (cf. Adler et al. 2003; Conard and Adler 1997; Roebroeks 1988). The raw material groups were defined by the combination of geophysical traits, such as grain size, inclusions, halos, opacity or cortex type, macroscopically and microscopically identified and analysed (Machado et al. 2017; Molina et al. 2010). This methodology was carried out following previous petrological and geological studies in the frame of this project (cf.
Molina 2015): these focused on both microscopic and macroscopic analysis of main geophysical traits of many representative flint samples collected from the primary and secondary sources over all the Serpis, Polop and Barxell river courses, and in the Mariola, La Serreta and La Font Roja mountain ranges; post-depositional alterations were also taken into account in order to establish the primary or secondary origin of the archaeological flint record and to relate the finds to prime raw material blocks to put RMUs together. This method was systematically applied on the record studied for this paper with a high but indefinite confidence interval due to the microscopic analysis of geophysical features present within every flint find.

For this work, we have discarded burnt and altered items that cannot be grouped within any of the defined RMUs, as well as the single tools and the isolated pieces that make an RMU of only one specimen each. Even if we consider that burnt and altered lithic remains and single tools contain a high degree of taphonomic and behavioural indications (Dorta et al. 2010; Machado et al. 2017), the impossibility of including these remains within any RMU makes them unsuitable for the current study. Therefore, the total number of the observed lithic remains is 216 , from which there are only four refitting sets of two specimens each (Table 1). The refitting analysis was carried out taking into account the entire lithic sample, even if the refitting sets are scarce and comprise a few elements each.

Analysis of the lithic record was mainly focused on the definition of the technical trends and features of RMUs, and their spatial distribution. Due to the scarce number of refitting sets and specimens by RMU, the technological ascriptions have been carried out through the identification and observation of morpho-technical features.

Additionally, recognising these morpho-technical traits allows us to define the phases of the existing knapping sequences (cortex removal, preparation of the striking platforms, blank production for reconditioning the debitage surface, debitage production and final exploitation of the core) performed within the context of each RMU, in order to delimit

Table 2 Summarised division of the AUs into the new analytical dataframes expressed through the most significant factors

\begin{tabular}{|c|c|c|c|c|c|c|}
\hline $\mathrm{AU}$ & New analytical unit & Involved hearths & $\mathrm{N}$ of RMUs & Involved RMUs & $\mathrm{N}$ of raw material types & Tech. ascription \\
\hline \multirow[t]{2}{*}{3.2} & - & $\mathrm{H} 23$ & $?$ & $?$ & $?$ & $?$ \\
\hline & 3.2 .1 & $\mathrm{H} 22$ & 6 & $3.2 \_21-23,25,29,30$ & 3 & $\mathrm{RCL}$ \\
\hline \multirow[t]{2}{*}{4.1} & 4.1.1 & $\mathrm{H} 26$ & 5 & $4.1 \_3,4,6,10,11$ & 3 & RCL with non-L \\
\hline & 4.1 .2 & $\mathrm{H} 25$ & 8 & $4.1 \_1,2,5,7-9,12,13$ & 3 & RCL with non-L \\
\hline 5.1 & 5.1 & $\mathrm{H} 28$ & 8 & All of them (see Table 5) & 2 & RCL with non-L \\
\hline 5.2 & - & $\mathrm{H} 24, \mathrm{H} 27$ & 9 & All of them (see Table 6) & 3 & $?$ \\
\hline \multirow[t]{3}{*}{5.3} & 5.3 .1 & $\mathrm{H} 31$ & 4 & $5.3 \_5,13,14,16$ & 3 & RCL with non-L \\
\hline & 5.3 .2 & $\mathrm{H} 29$ & 5 & $5.3 \_3,4,9,15,19$ & 3 & $\mathrm{RCL}$ \\
\hline & 5.3 .3 & $\mathrm{H} 32$ & 13 & $5.3 \_1,2,6-8,10-12,17,18,20-22$ & 5 & RCL with non-L \\
\hline
\end{tabular}


Table 3 Technological data from AU 3.2

Archaeostratigraphic unit 3.2

\begin{tabular}{|c|c|c|c|c|c|c|c|c|}
\hline \multirow[t]{2}{*}{ Raw material } & \multirow[t]{2}{*}{ RMU } & \multirow[t]{2}{*}{ Specimens } & \multirow[t]{2}{*}{ Refits } & \multicolumn{4}{|c|}{ Technical stage } & \multirow[t]{2}{*}{ Tech. features } \\
\hline & & & & $\mathrm{CR}$ & PREP & DP & FEC & \\
\hline Serreta & $3.2 \_1$ & 2 & - & - & 2 & - & - & Undiagnosed \\
\hline Serreta & $3.2 \_2$ & 2 & - & - & - & - & 2 & $\mathrm{RCL}$ \\
\hline Font Roja & $3.2 \_3$ & 2 & - & - & 2 & - & - & Up non-L \\
\hline Mariola & $3.2 \_4$ & 3 & - & - & - & - & 3 & Up non-L (FEC Bp non-L) \\
\hline Beniaia & $3.2 \_5$ & 2 & - & - & 2 & - & - & $\mathrm{Up}$ \\
\hline Serreta & $3.2 \_6$ & 3 & - & - & 3 & - & - & RCL \\
\hline Mariola & $3.2 \_7$ & 2 & - & 1 & - & - & 1 & $\mathrm{RCL}$ \\
\hline Serreta & $3.2 \_8$ & 2 & - & - & 2 & - & - & Up \\
\hline Mariola & 3.2_9 & 2 & - & - & 2 & - & - & Up \\
\hline Serreta & $\frac{3.2}{10}$ & 3 & $\begin{array}{l}\mathrm{R} 1 \\
-\end{array}$ & $\begin{array}{l}- \\
-\end{array}$ & $\begin{array}{l}2 \\
-\end{array}$ & - & $\begin{array}{l}- \\
1\end{array}$ & $\mathrm{RCL}$ \\
\hline Serreta & $3.2 \_11$ & 2 & - & - & - & 1 & 1 & Up \\
\hline Font Roja & $3.2_{12}$ & 4 & - & 1 & 3 & - & - & $\mathrm{RCL}$ \\
\hline Mariola & $3.2_{13}$ & 6 & - & 3 & - & . & 3 & Up non-L \\
\hline Mariola & $3.2_{-}$ & 4 & - & 1 & 1 & 1 & 1 & Up? \\
\hline Mariola & $3.2_{15}$ & 2 & - & - & & - & - & Undiagnosed \\
\hline Serreta & $3.2_{16}^{-}$ & 4 & - & _ & & - & - & $\mathrm{RCL}$ \\
\hline Serreta & $3.2-17$ & 2 & - & & - & - & 2 & $\mathrm{RCL}$ \\
\hline Serreta & $3.2_{18}$ & 3 & - & & 3 & - & - & $\mathrm{RCL}$ \\
\hline Mariola & $3.2_{19}$ & 2 & - & 1 & 1 & - & - & $\mathrm{RCL}$ \\
\hline Beniaia & $3.2_{20}$ & 2 & - & - & 2 & - & - & $\mathrm{RCL}$ \\
\hline Font Roja & $3.2_{21}$ & 2 & - & 1 & - & - & 1 & $\mathrm{Ud}$ \\
\hline Serreta & $3.2-$ & 3 & - & - & 3 & - & - & $\mathrm{RCL}$ \\
\hline Beniaia & 3.2 & & - & 2 & - & - & - & Undiagnosed \\
\hline Mariola & $3.2_{24}$ & 3. & - & - & 3 & - & - & $\mathrm{RCL}$ \\
\hline Mariola & $3.2_{25}$ & 2 & - & 2 & - & - & - & Undiagnosed \\
\hline Mariola & $3.2_{26}$ & 2 & - & - & 2 & - & - & RCL \\
\hline Serreta & $3.2_{27}$ & 2 & - & - & 2 & - & - & RCL \\
\hline Beniaia & $3.2_{28}$ & 2 & - & 1 & - & - & 1 & Levallois \\
\hline Serreta & $3.2_{29}$ & 2 & - & - & 2 & - & - & $\mathrm{RCL}$ \\
\hline Beniaia & $3.2-$ & 2 & - & - & 2 & - & - & $\mathrm{RCL}$ \\
\hline Serreta & $3.2-$ & 2 & - & 2 & - & - & - & Undiagnosed \\
\hline Beniaia & $3.2_{32}$ & 2 & - & - & 2 & - & - & Ud Levallois \\
\hline Serreta & & 2 & - & - & 1 & 1 & - & Up \\
\hline
\end{tabular}


Table 3 (continued)

Archaeostratigraphic unit 3.2

\begin{tabular}{|c|c|c|c|c|c|c|c|c|}
\hline \multirow[t]{2}{*}{ Raw material } & \multirow[t]{2}{*}{ RMU } & \multirow[t]{2}{*}{ Specimens } & \multirow[t]{2}{*}{ Refits } & \multicolumn{4}{|c|}{ Technical stage } & \multirow[t]{2}{*}{ Tech. features } \\
\hline & & & & $\mathrm{CR}$ & PREP & DP & FEC & \\
\hline
\end{tabular}

$R M U$, raw material unit; $T E C H$., technological; $C R$, cortex removal; $P R E P$, preparation of the core; $D P$, debitage products; $F E C$, final exploitation of the core; $R C L$, recurrent centripetal Levallois; $U p$, unipolar; non- $L$, non-Levallois; $B p$, bipolar; $U d$, unidirectional

technical activities which were carried out on the site. In most cases, it also allows us to classify these sequences into general technological ascriptions.

Moreover, this work follows the methodology established in previous archaeostratigraphic studies at the site (Machado et al. 2017) (Fig. 3), which includes faunal and lithic remains, and combustion structures. We use three-dimensional geographic information system (GIS) software models (using ArcGIS® ArcMap v10.2.2 and ArcScene v10.2.2) to delve into the spatial relationships between the different RMUs and hearths within each AU. The spatial coordinates with which we have worked were taken and recorded using a Sokkia ${ }^{\circledR}$ iM-50 total station comprising its standard software. The defining elements of the AUs were: the identification of natural sedimentary depositions without anthropogenic input between bedded materials, the location (stratigraphic and horizontal position) of hearths, the archaeological surfaces
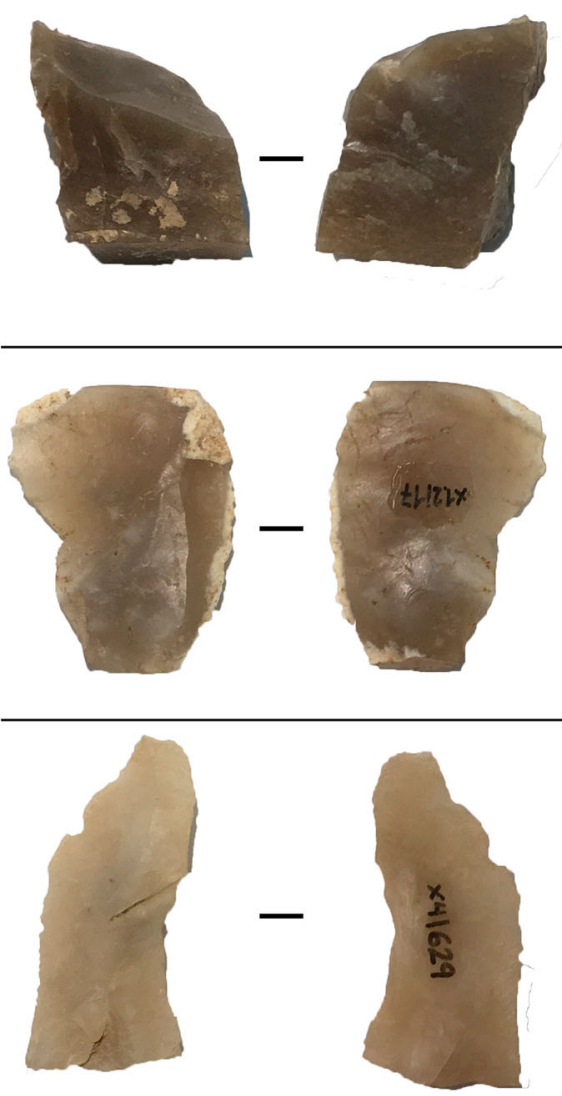

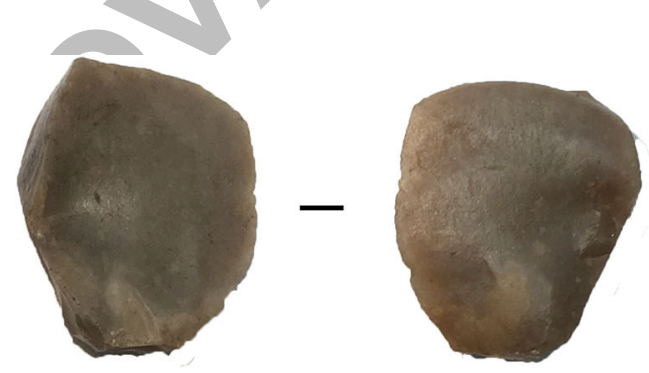

1

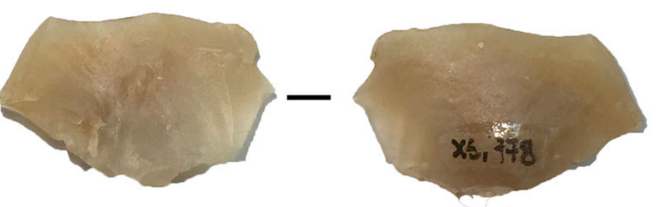

2
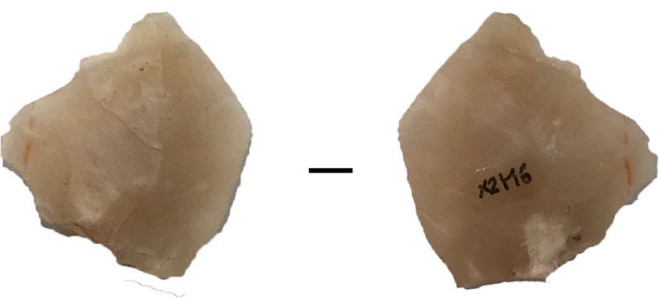

\section{3}

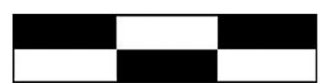

Fig. 4 Specimens comprised within the RMUs 3.2 21 (1), 3.223 (2) and 3.2 25 (3). These are three from the six RMUs belonging to the 3.2.1 occupation episode 

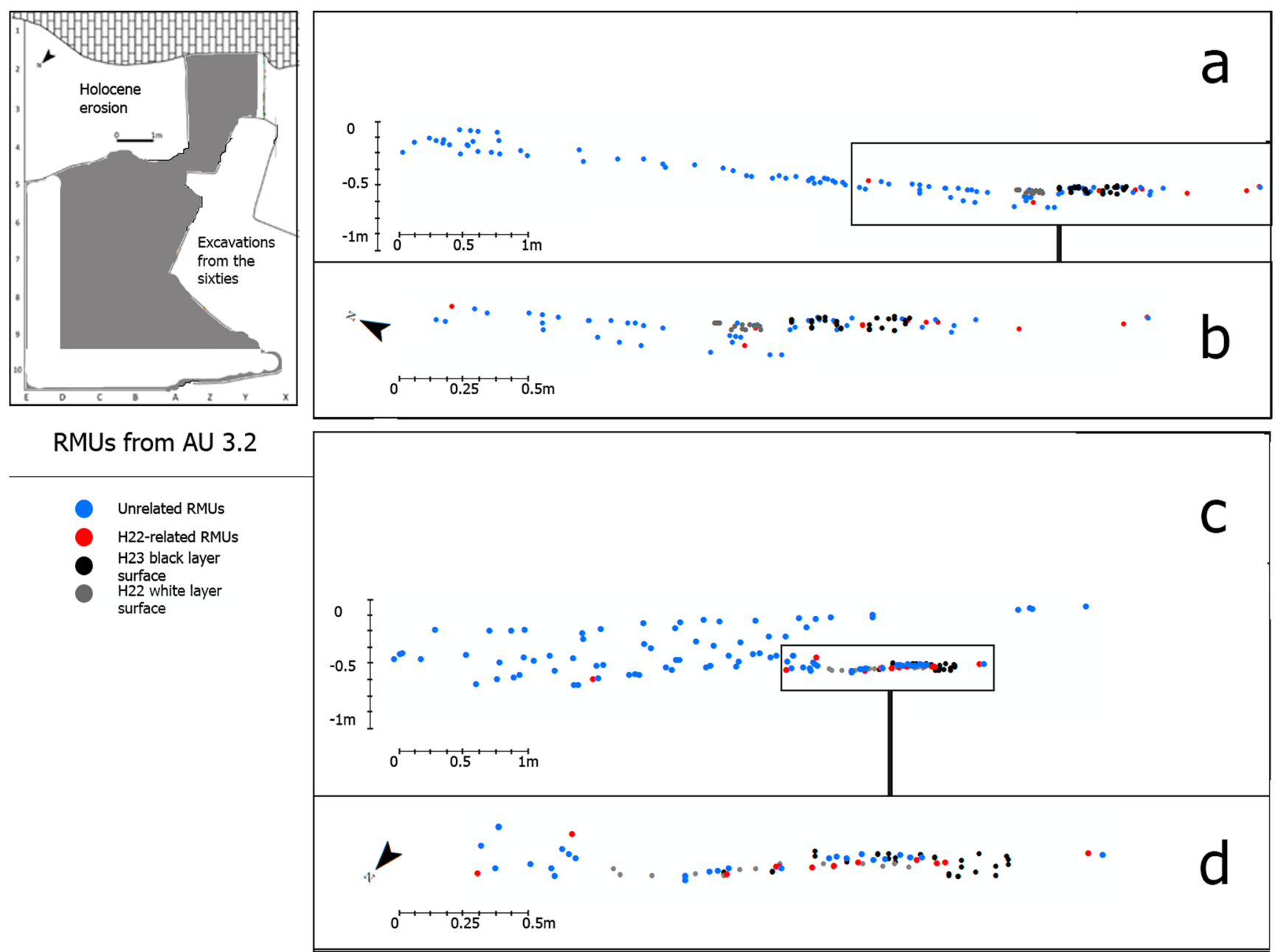

Fig. 5 Cross-sections showing the stratigraphic position of the RMUs belonging to AU 3.2 from north to south (a) and from east to west (c).

identified during fieldwork and post-excavation analyses and the stratigraphic relationship of the SU xa lithic record.

We apply here these factors to the distinct RMUs in order to differentiate several depositional events within the context of the AU. The lithic record from both AUs $3 \mathrm{e}$ and $4 \mathrm{e}$ (Figs. 1 and 3 ), located in the outer excavation area, has been discarded due to the lack of connecting elements that link it to the inner AUs record, in the case of $3 \mathrm{e}$, and the absence of combustion structures, in both cases. Hearths are key features for working towards the goal of dissecting the micropalimpsests (e.g. Machado et al. 2013, 2019; Sañudo et al. 2012), because the top of the burnt soils represent occupation surfaces.

\section{Results}

Spatial and technological inferences from AUs 3.2, 4.1, 5.1, 5.2 and 5.3 are shown and explained below. On one hand,
The area of the hearths also has been enlarged in both cases for a clearer view (b and d)

several individualised assemblages corresponding to single occupation episodes have been identified amongst the context of the distinct AUs: one in 3.2 (named 3.2.1), two in 4.1 (4.1.1 and 4.1.2), one in 5.1 (5.1) and three in 5.3 (5.3.1, 5.3.2 and 5.3.3). On the other hand, Levallois conceptions predominate, but other non-Levallois schemes are present within the lithic record (Table 2). Thus, in this section, we display the technological and technical information provided by the lithic record and the spatial and archaeostratigraphic data inferred through the stratigraphic and horizontal relationships between hearths and RMUs.

\section{Archaeostratigraphic unit $\mathbf{3 . 2}$}

The lithic record from AU 3.2 comprises 82 flint remains, classified in 33 RMUs of Serreta (43.9\%), Mariola (34.1\%), Font Roja (7.3\%) and Beniaia (14.6\%) flint types (Table 3) (Fig. 4). It is the largest amount of lithic material within the current study and displays the presence of a two-specimen refit (R1 in RMU 3.2 10). These RMUs consist of 17 
Table 4 Technological data from AU 4.1

Archaeostratigraphic unit 4.1

\begin{tabular}{|c|c|c|c|c|c|c|c|c|}
\hline \multirow[t]{2}{*}{ Raw material } & \multirow[t]{2}{*}{ RMU } & \multirow[t]{2}{*}{ Specimens } & \multirow[t]{2}{*}{ Refits } & \multicolumn{4}{|c|}{ Technical stage } & \multirow[t]{2}{*}{ Tech. features } \\
\hline & & & & $\mathrm{CR}$ & PREP & DP & FEC & \\
\hline Serreta & 4.111 & 10 & - & 2 & 8 & - & - & RCL \\
\hline Mariola & $4.1 \_2$ & 2 & - & - & 2 & - & - & $\mathrm{RCL}$ \\
\hline Mariola & $4.1 \_3$ & 2 & - & - & - & - & 2 & Ud discoidal \\
\hline Serreta & 4.1_4 & 2 & - & - & 2 & - & - & RCL (1) and core-flake RCL (1) \\
\hline Beniaia & $4.1 \_5$ & 2 & - & - & 2 & - & - & Levallois? \\
\hline Mariola & 4.1_6 & 2 & - & - & - & - & 2 & $\mathrm{RCL}$ \\
\hline Serreta & $4.1 \_7$ & 2 & - & - & 2 & - & - & Up (1) and core-flake RCL (1) \\
\hline Serreta & $4.1 \_8$ & 2 & - & 1 & 1 & - & - & Undiagnosed \\
\hline Serreta & 4.1_9 & 2 & - & - & 2 & - & - & $\mathrm{RCL}$ \\
\hline Font Roja & $4.1_{10}$ & 2 & - & - & 2 & - & - & Orth Levallois (1) and RCL (1) \\
\hline Serreta & $4.1 \_11$ & 2 & - & - & 2 & - & & $\mathrm{RCL}$ \\
\hline Serreta & $4.1_{12}$ & 2 & - & 1 & 1 & - & & RCL \\
\hline Beniaia & $4.1_{-13}$ & 2 & - & - & 1 & & & RCL (1) and Ud (1) \\
\hline
\end{tabular}

$R M U$, raw material unit; $T E C H$., technological; $C R$, cortex removal; $P R E P$, preparation of the core; $D P$, debitage products; $F E C$, final exploitation of the core; $R C L$, recurrent centripetal Levallois; orth, orthogonal; $U d$, unidirectional

recurrent centripetal Levallois (RCL), 3 unipolar Levallois, 4 unipolar non-Levallois and 9 undiagnosed knapping sequences. All of these display a fragmentary character, but the cases of the RMUs 3.2_10 and 3.2_14 are noteworthy because every single phase of the technical sequence can be recognised.

This AU comprises two hearths: $\mathrm{H} 22$ and H23. Only the RMUs 3.2_21, 22, 23, 25, 29 and 30 (Fig. 5) have been related to one of them (H22). This correlation has been possible due to the fact that all of them are positioned within $\mathrm{H} 23$ black layer, and horizontally associated to $\mathrm{H} 22$ white layer, if we keep in mind that in this area the assemblage declines in a southernly direction. It has not been possible to establish this kind of relationship between the rest of the RMUs and the hearths, mainly due to the large spreading of AU 3.2 lithic assemblage (it covers about $32 \mathrm{~m}^{2}$ of the excavation area). The distance between the RMUs and the hearths (Fig. 3), as well as their horizontal homogeneity and suitable correspondence to the ascending slope of the assemblage in the central and shouthern parts of the excavation area (Fig. 5), is also a limiting factor.

\section{Archaeostratigraphic unit 4.1}

AU 4.1 comprises 34 lithic remains, ascribed to 13 different flint RMUs of Serreta (53.8\%), Mariola (23\%), Font Roja (7.7\%) and Beniaia (15.4\%) (Table 4) (Figs. 6 and 7). All the RMUs possess a fragmentary character, and there is none in which every phase of the operational sequence can be recognised. The Levallois sequences here are predominant over other types of knapping systems. There are 10 examples of this, from which 9 are genuine recurrent centripetal sequences, and another one shows an indeterminate modality. One of the former additionally displays a unipolar non-Levallois strategy at the final exploitation of the core (RMU 4.1_13). Besides, there are two RMUs on which unipolar non-Levallois procedures have been performed. The thirteenth one is undiagnosed (RMU 4.1_8).

This AU comprises two hearths (H25 and H26) that are near to each other, but not overlapping (Fig. 8). Neither do they have clear evidence of a direct stratigraphic relationship between them. However, the spatial analysis of the associated RMUs points to the existence of two distinguishable assemblages: a lower one, integrated by $\mathrm{H} 25$ and the RMUs 4.1_3, 4, 6, 10 and 11, and an upper one, consisting of $\mathrm{H} 26$ and the RMUs 4.1_1, 2, 5, 7, 8, 9, 12 and 13. The H26 black layer separates the RMUs from both assemblages, and, at the same time, they are horizontally associated to the white layers of the respective hearths. This has to be added to the fact that H25 white layer is stratigraphically associated with H26 black layer (Fig. 9).

\section{Archaeostratigraphic unit 5.1}

This AU comprises the lowest amount of lithic material: 19 remains, classified in 8 RMUs made on Serreta $(62.5 \%)$ and 


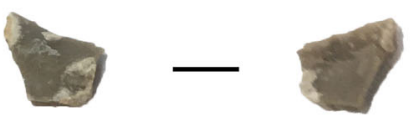

1
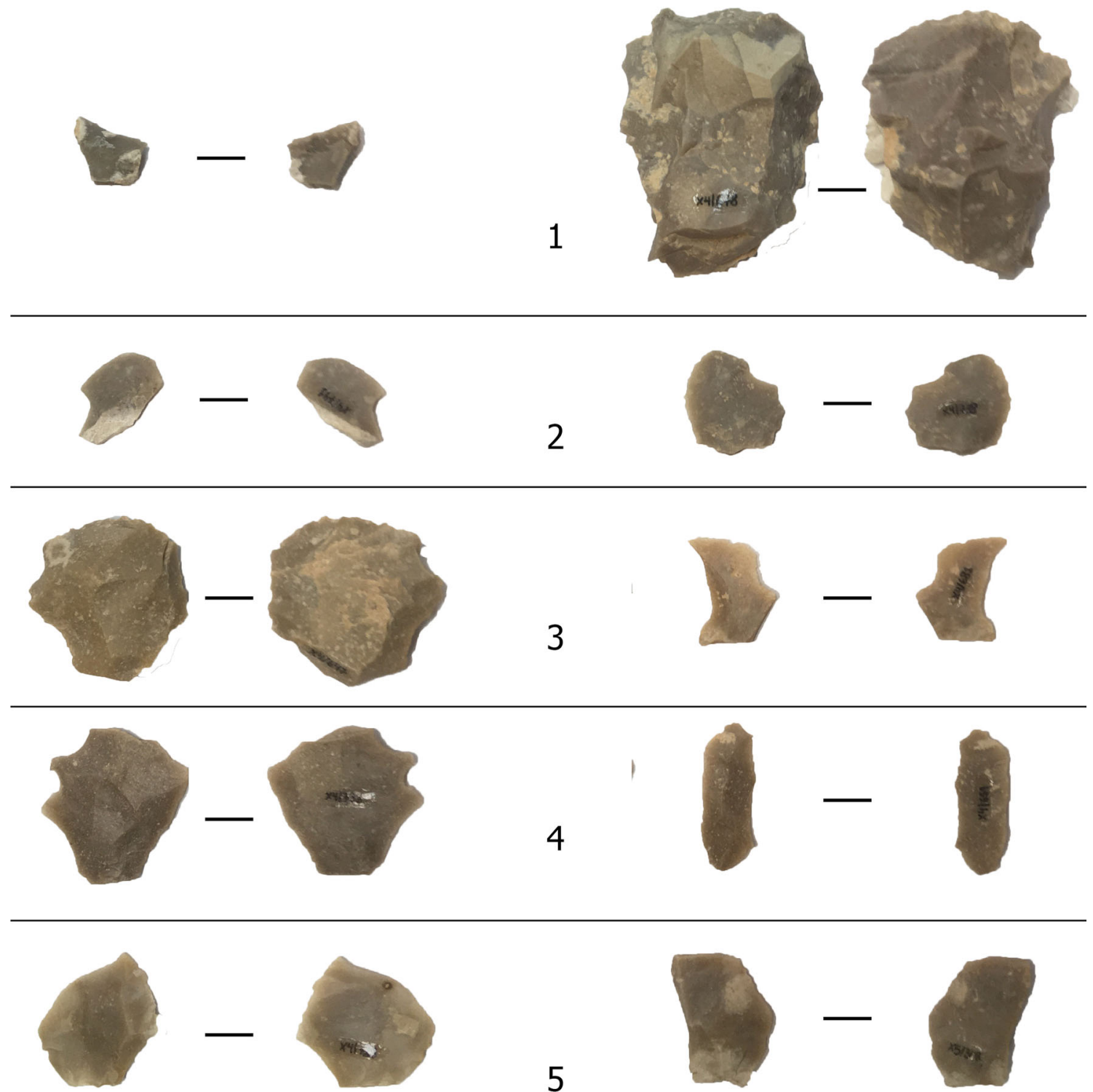

5

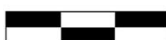

Fig. 6 Specimens comprised within the RMUs 4.1_3 (1), 4.1_4 (2), 4.1_6 (3), 4.1_10 (4) and 4.1_11 (5). These are the five RMUs belonging to the 4.1.1 occupation episode

Mariola (37.5\%) types, and no refits (Table 5) (Fig. 10). Technomorphologically, AU 5.1 flint production comprises 7 RCL sequences. RMU 5.1_7 is an exception since it is integrated by a pseudo-Levallois flake and a unipolar nonLevallois core.

Regarding the spatial perspective, AU 5.1 covers a relatively small area (nearly $2 \mathrm{~m}^{2}$ ). Lithic finds are distributed in a half-circle around the northernmost part of $\mathrm{H} 28$ (Fig. 11), which is the only existing hearth within this AU. Only RMUs 5.1_2, 5.1_3 and 5.1_6 present a direct spatial connection with the top of $\mathrm{H} 28$ black layer since they occupy the same surface. These also display a slight dip towards the travertine wall, as well as the remaining RMUs.

\section{Archaeostratigraphic unit $\mathbf{5 . 2}$}

Similar to AU 5.1, 5.2 is composed of a small assemblage consisting of 25 flint remains, associated to 9 RMUs of Serreta (55.5\%), Mariola (22.2\%) and Beniaia (22.2\%) types (Table 6); it also contains a couple of two-specimen refits (R2 in RMU 5.2 1 and R3 in 5.2 5). In this case, 4 sequences are Levallois ( 2 RCL and 2 unidirectional), 2 are Kombewa and the remaining 3 undiagnosed. 
1
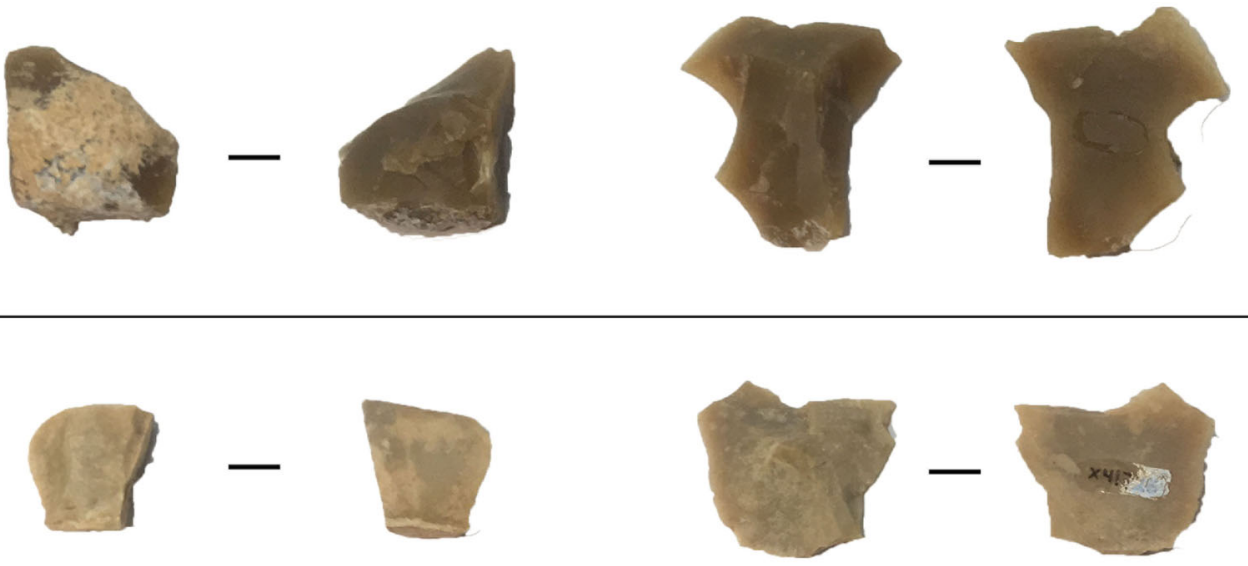

2

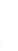

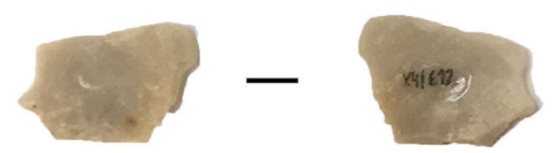

3
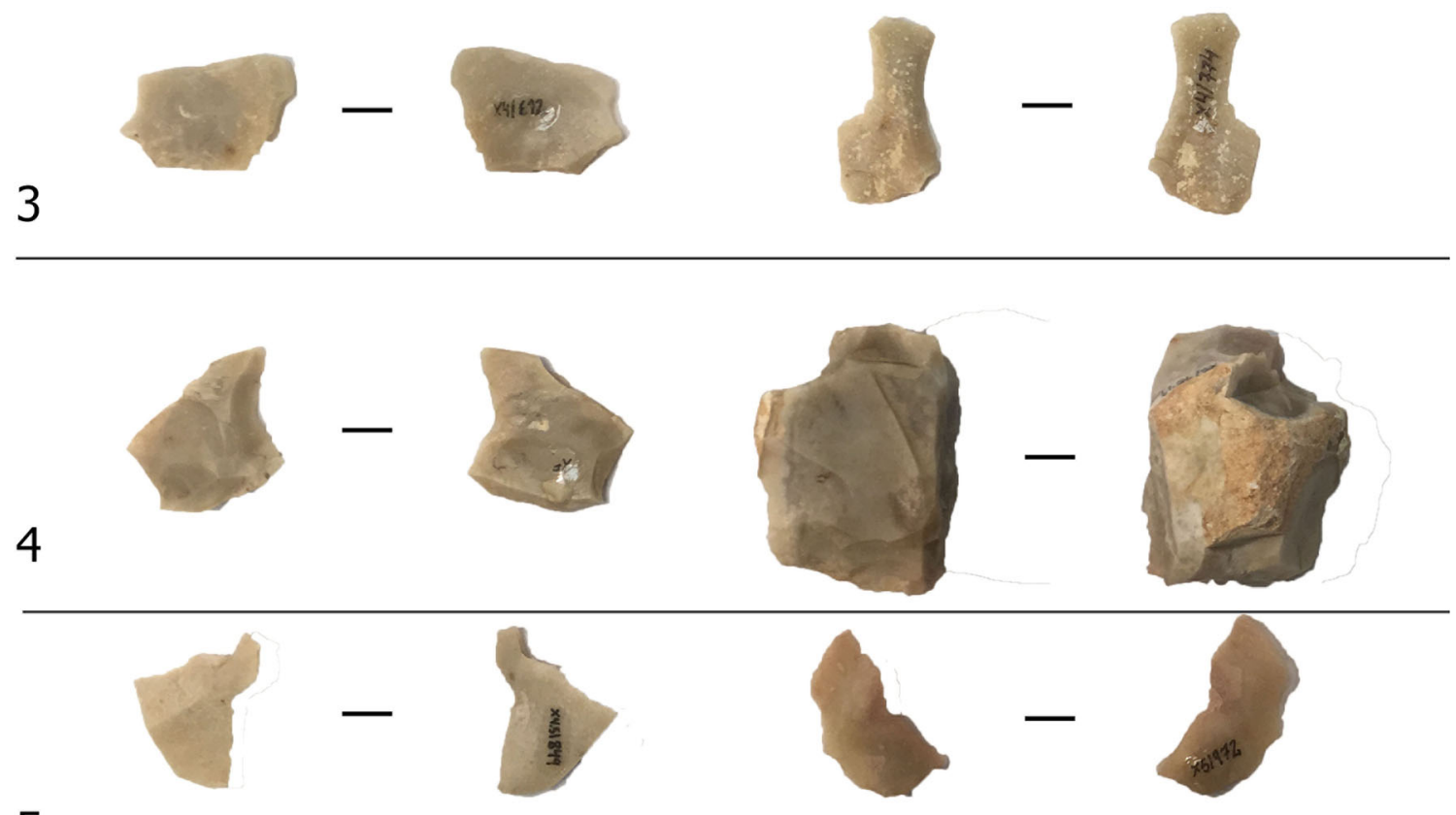

5

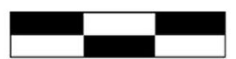

Fig. 7 Specimens comprised within the RMUs 4.1_7 (1), 4.1_8 (2), 4.1_9 (3), 4.1_12 (4) and 4.1_13 (5). These are five from the eight RMUs belonging to the 4.1.2 occupation episode

$\mathrm{H} 24$ and $\mathrm{H} 27$ are the only hearths present in this AU. The lithic assemblage distribution does not have a semicircular shape around these structures as is evident in the other cases (Fig. 12), and shows an ascending slope to the travertine wall and northerly. In this case, the hearths are not overlapping each other either, so we are not immediately able to establish a direct stratigraphic correlation neither between them nor with the associated RMUs.

\section{Archaeostratigraphic unit $\mathbf{5 . 3}$}

AU 5.3 comprises 56 lithic remains, classified into 22 flint RMUs of Serreta (45.5\%), Mariola (27.3\%),
Beniaia (13.6\%), Font Roja (4.5\%) and unknown types (9.1\%) (Table 7) (Figs. 13, 14 and 15). Only one twospecimen refit has been recognised in this AU (R4 in RMU 5.2_11). In technomorphological terms, 13 of the sequences are Levallois (12 RCL and 1 unidirectional), 4 non-Levallois (1 discoidal and 3 of indeterminate strategies) and another 4 are undiagnosed.

This lithic assemblage has been linked to 3 combustion structures: $\mathrm{H} 29$ and $\mathrm{H} 31$, which are both represented only by their respective black layers, and $\mathrm{H} 32$, which has a well-preserved ash layer. The spatial data from this $\mathrm{AU}$ indicates that the hearths are overlapping each other. $\mathrm{H} 31$ is partially overlapping $\mathrm{H} 29$, and both of them are covering H32 (Fig. 16). The lithic record forms 

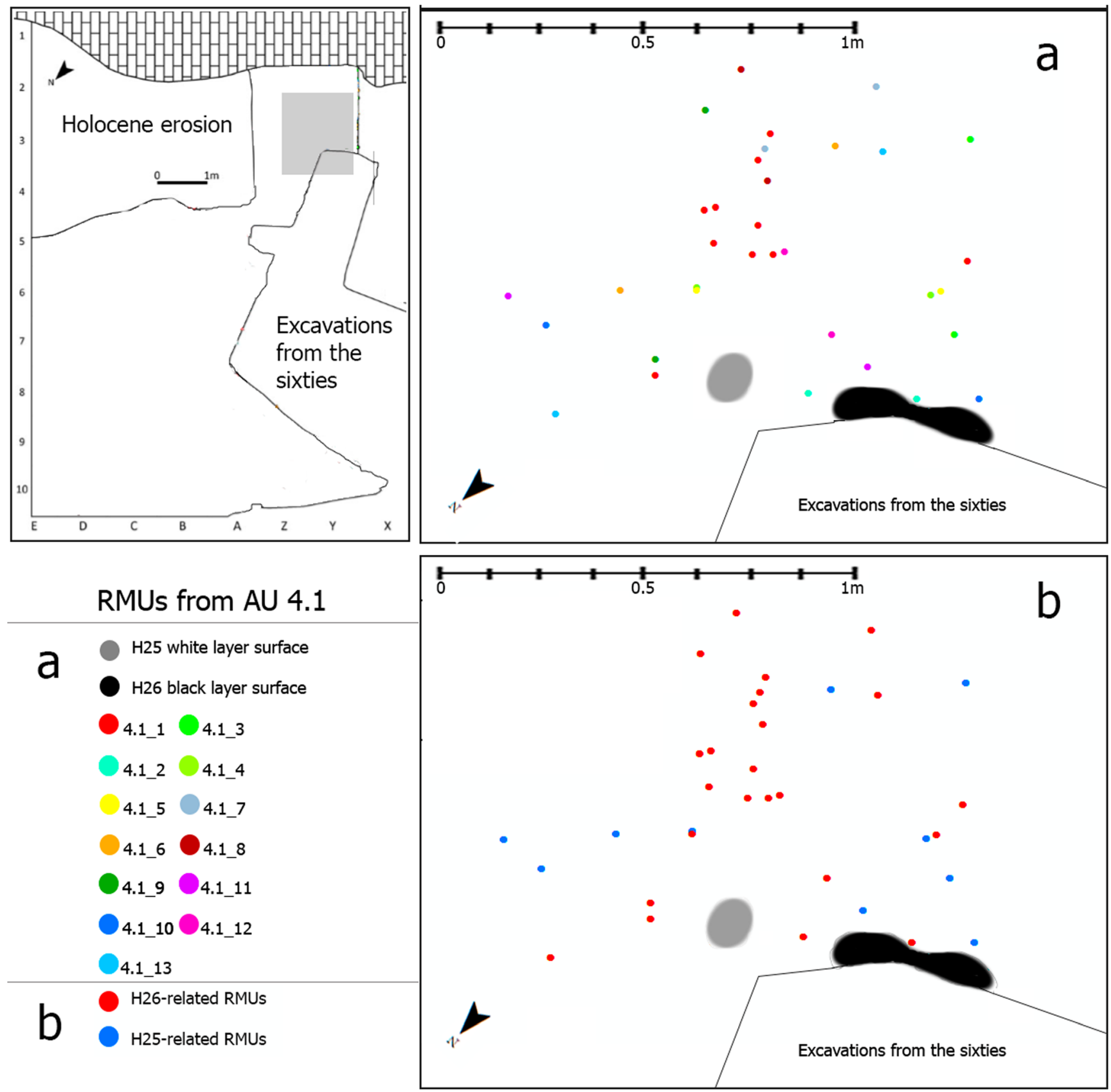

Fig. 8 Maps displaying the spatial distribution of the RMUs belonging to AU 4.1 (a), and the stratigraphic relation with the hearths (b)

a semicircular shape around the northeastern part of the hearths, and it is concentrated in an area of almost $2 \mathrm{~m}^{2}$. The plots of these RMUs show a gentle deep towards the northernmost part of the assemblage and away from the hearths, where they pinch out (Fig. 17). Only 6 RMUs have direct contact with the surface of the hearths: 5.3_5, 13 and 16 are located just on top of H31 black layer or in its immediate surroundings; 5.3 _ 4 is positioned over $\mathrm{H} 29$ and H32, but clearly beneath H31; finally, 5.3_18 is overlapped by $\mathrm{H} 29$ and $\mathrm{H} 31$, and, together with $5.3 \_17$, is in stratigraphic association with $\mathrm{H} 32$.

This makes it possible to distinguish 3 assemblages that are superimposed, to which the remaining RMUs have been assigned using stratigraphic and spatial correlations. The lower one, structured around $\mathrm{H} 32$, is composed of 11 more RMUs (5.3_1, 2, 6, 7, 8, 10, 11, 12, 20, 21 and 22); the middle assemblage, related to H29, of 4 more (5.3_3, 9, 15 and 19); and, finally, the upper one, around $\mathrm{H} 31$, comprises only 1 more RMU (5.3_14).

\section{Discussion}

The search of a higher temporal resolution that approaches the single occupation frame among these 


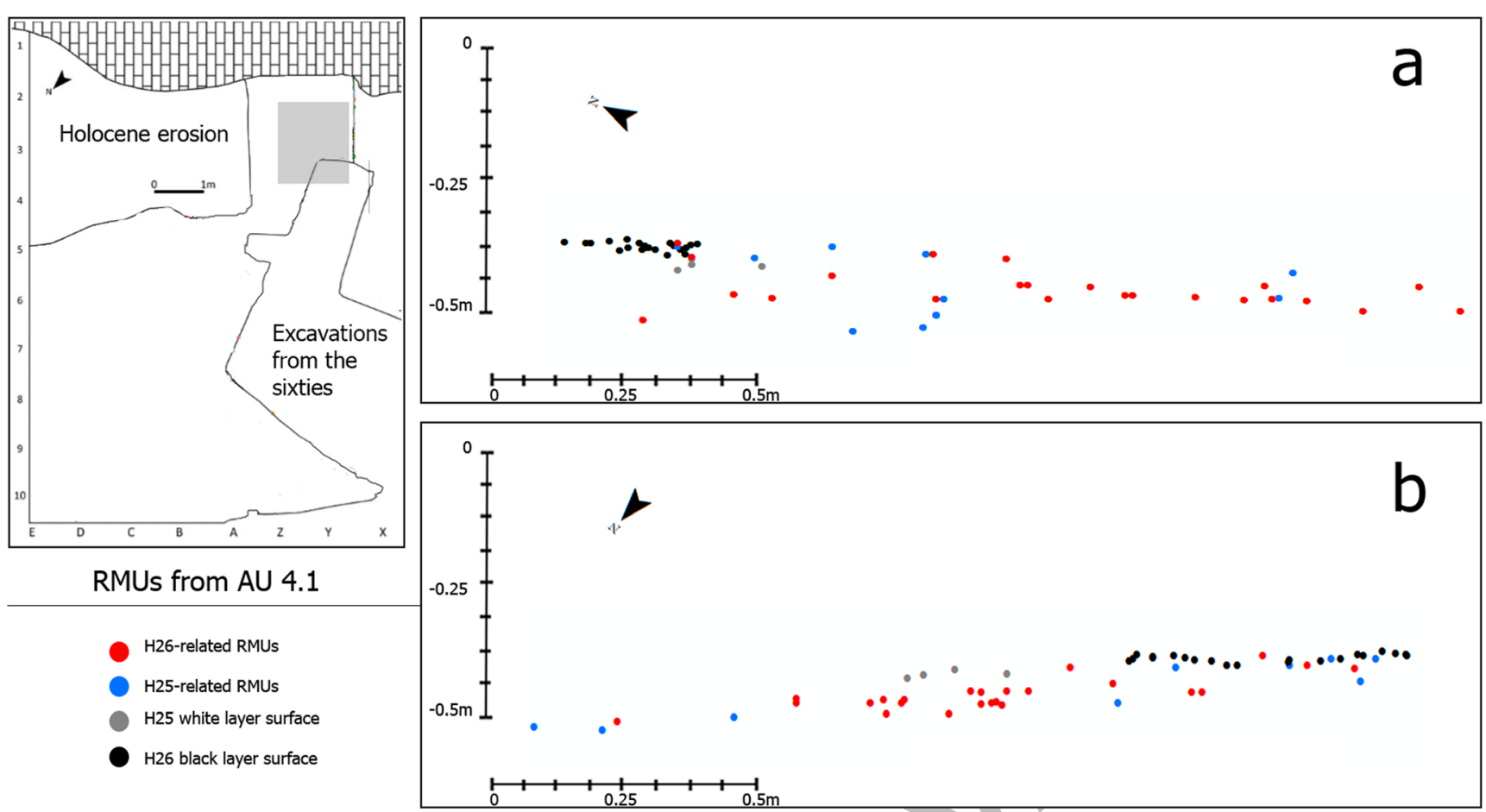

Fig. 9 cross-sections showing the archaeostratigraphic relation between the RMUs and the hearths from AU 4.1 from north to south (a) and from east to west (b)

micropalimpsests from a spatial and technological perspective has allowed us to establish a potential range of human occupation episodes. Specifically, all the lithic record and the hearths have been related to single occupation episodes in 4.1, 5.1 and 5.3 (analytical units 4.1.1, 4.1.2, 5.1, 5.3.1, 5.3.2 and 5.3.3, respectively); a part of the lithic record and one hearth out of two have been associated to one episode in 3.2 (analytical unit 3.2.1); and 5.2 remains a micropalimpsest.

In this discussion, we highlight problematic aspects encountered for each of the AUs and integrate archaeozoological data, such as taxonomic variability and minimal number of individuals by taxon, to further explore inter-occupational and intra-occupational diachrony within these new frameworks. Subsequently, we discuss the results from a technological perspective in order to characterise these new analytical frames and to infer technical behaviours within the context of the single occupation episode. Finally, we introduce several behavioural issues related to mobility models and technical strategies.

\section{Delving into depositional events as analytical frames: the single occupation issue}

Considering each RMU, single tool and isolated artefact as possibly representing a single anthropogenic input, we have observed variability among the AUs and a potentially high number of occupation episodes. However, if we take into consideration the faunal remains from the corresponding units, this high number is reduced regarding the minimal number of individuals by taxon. Furthermore, the resulting number is even lower if we take into account the amount of hearths by AU (Table 9).

In spite of this, the use of our archaeostratigraphic approach has allowed us to identify assemblages linked to intraoccupational depositional episodes and indicators of interoccupational diachrony to differentiate these episodes. Our new analytical units reflect a diverse scenario, which we discuss below.

\section{A single occupation episode in 5.1}

AU 5.1 presents the lowest amount of potential single inputs from all the studied AUs (Table 9). It corresponds to a hearth-related assemblage, in which $\mathrm{H} 28$ is the only combustion structure, and is made up of eight RMUs derived from two different flint types. These RMUs display a very fragmentary nature and a discontinuous recognition of the exploitation phases of the knapping sequences. Most of the 5.1 lithic finds ascribed to RMUs (14 out of 19) belongs to RCL blank production. Additionally, out of the three preys mainly hunted by Neanderthals in this region (Cervus elaphus, Capra pyrenaica and Equus ferus), the AU 5.1 faunal record is formed by at least two wild goats and three wild horses. This assemblage also comprises a chamois (Rupicapra sp.). 
Table 5 Technological data from AU 5.1

Archaeostratigraphic unit 5.1

\begin{tabular}{|c|c|c|c|c|c|c|c|c|}
\hline \multirow[t]{2}{*}{ Raw material } & \multirow[t]{2}{*}{ RMU } & \multirow[t]{2}{*}{ Specimens } & \multirow[t]{2}{*}{ Refits } & \multicolumn{4}{|c|}{ Technical stage } & \multirow[t]{2}{*}{ Tech. features } \\
\hline & & & & $\mathrm{CR}$ & PREP & $\mathrm{DP}$ & FEC & \\
\hline Serreta & 5.11 & 2 & - & - & 2 & - & - & RCL \\
\hline Serreta & $5.1 \_2$ & 3 & - & 2 & 1 & - & - & RCL \\
\hline Serreta & $5.1 \_3$ & 3 & - & - & 3 & - & - & RCL \\
\hline Serreta & 5.1_4 & 2 & - & 1 & 1 & - & - & Undiagnosed \\
\hline Mariola & $5.1 \_5$ & 3 & - & - & 3 & - & - & $\mathrm{RCL}$ \\
\hline Serreta & 5.1_6 & 2 & - & - & 2 & - & - & RCL \\
\hline Mariola & $5.1 \_7$ & 2 & - & - & 1 & - & 1 & Up non-L (1) and RCL (1) \\
\hline Mariola & 5.18 & 2 & - & - & 2 & - & - & RCL \\
\hline
\end{tabular}

$R M U$, raw material unit; $T E C H$., technological; $C R$, cortex removal; $P R E P$, preparation of the core; $D P$, debitage products; $F E C$, final exploitation of the core; $R C L$, recurrent centripetal Levallois; $U d$, unidirectional; non- $L$, non-Levallois

Consequently, 5.1 record represents a short production of blanks on a couple of flint types around a single hearth that coexists with animal processing activities over a very small area, and no diachronic relations have been identified among such elements. This is why we corroborate our previous interpretation (Machado et al. 2017; Pérez et al. 2019) of this AU as a single occupation. This AU shows similar features with several
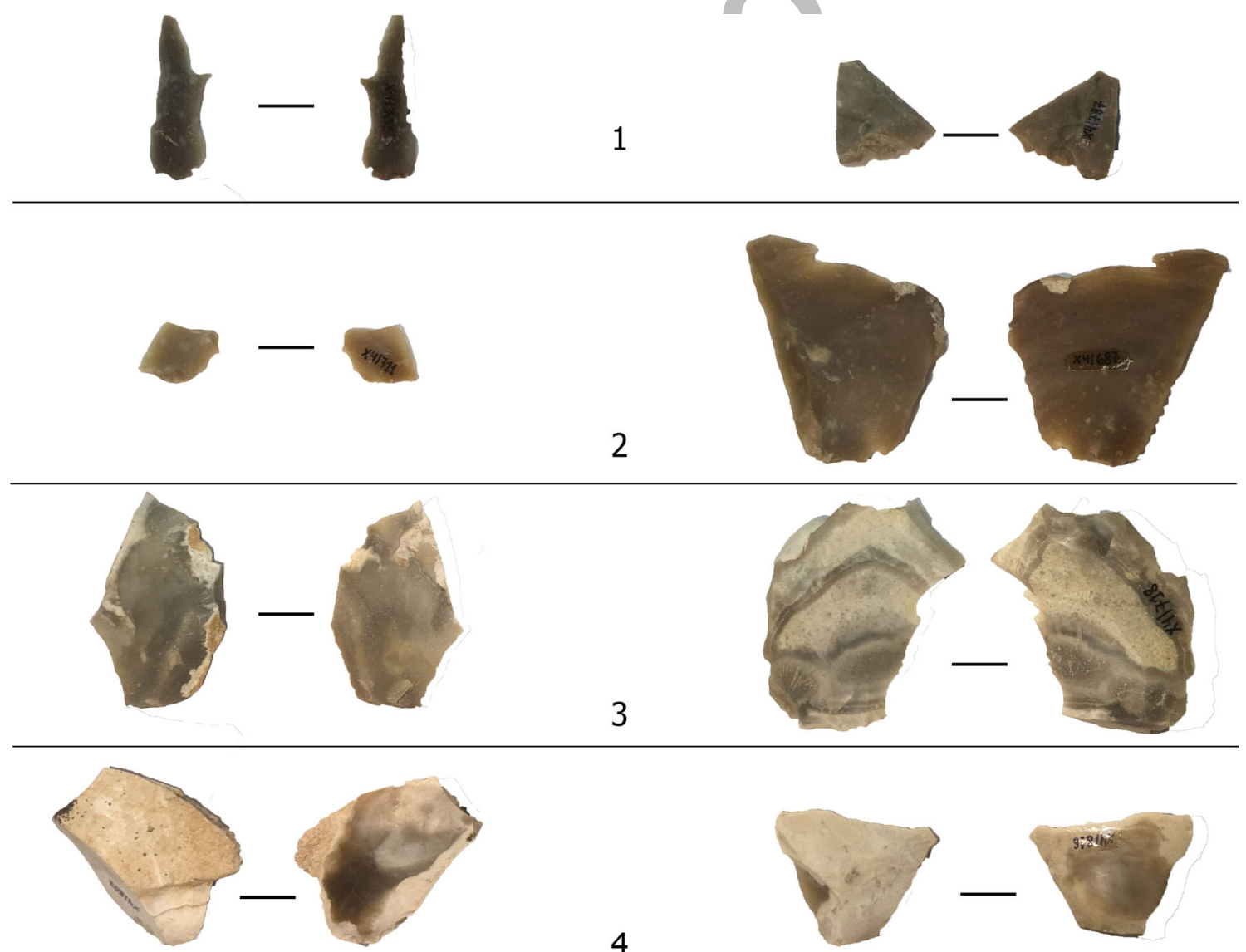

4

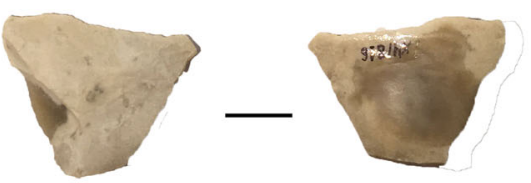

Fig. 10 Specimens comprised within the RMUs 5.1_1 (1), 5.1_6 (2), 5.1_7 (3) and 5.1_8 (4). These are four from the eight RMUs belonging to the 5.1 occupation episode 

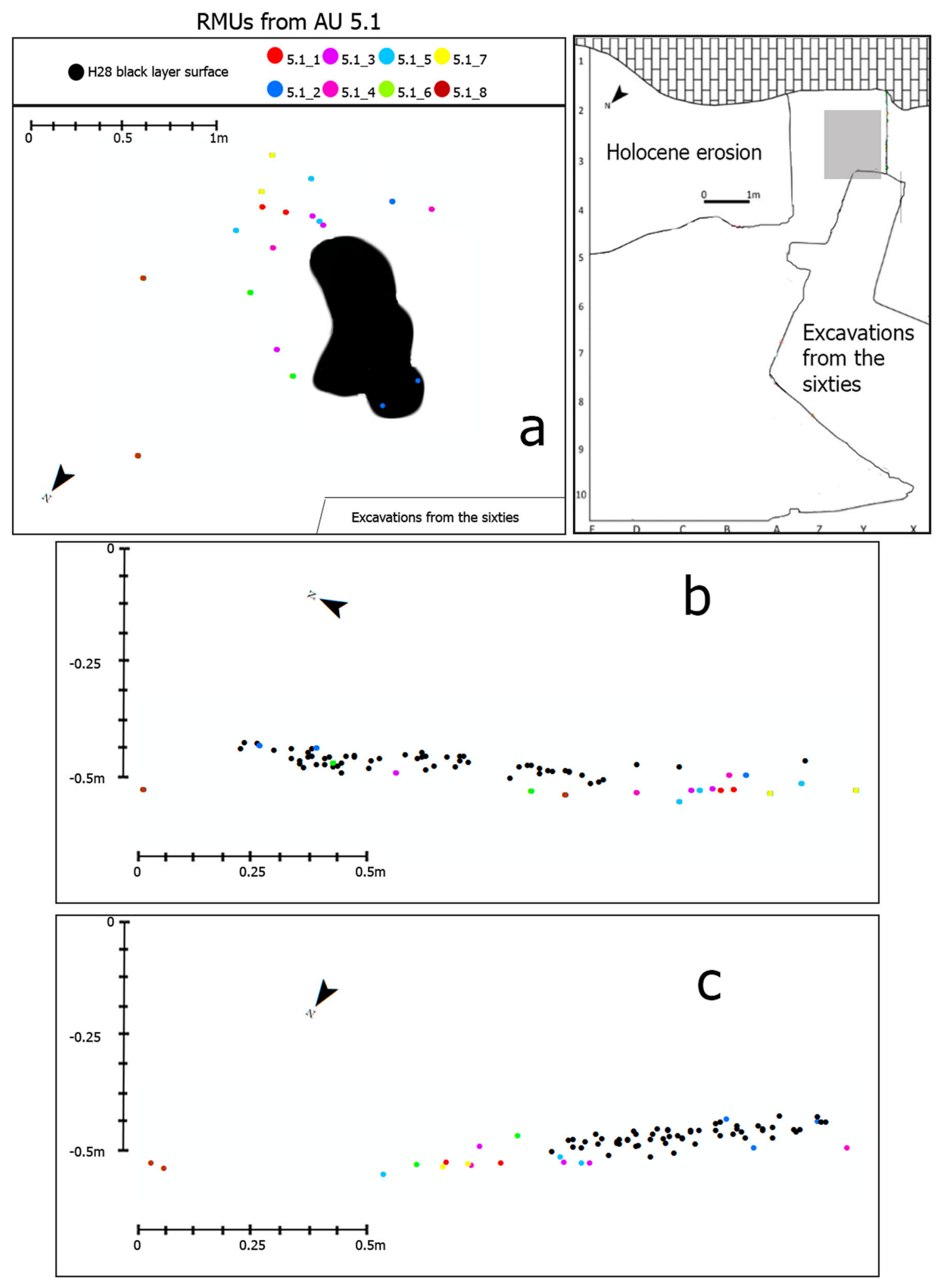

Fig. 11 Map that displays the spatial distribution of the RMUs belonging to AU 5.1 (a), and cross-sections showing the archaeostratigraphic relationship between the RMUs and the hearth from north to south (b) and from east to west (c)

individualised anthropogenic episodes documented at El Pastor (cf. Machado et al. 2019) and, thus, they might be considered together to formulate a predictive model towards interpreting the remaining AUs. 
Table 6 Technological data from AU 5.2

Archaeostratigraphic unit 5.2

\begin{tabular}{|c|c|c|c|c|c|c|c|c|}
\hline \multirow[t]{2}{*}{ Raw material } & \multirow[t]{2}{*}{ RMU } & \multirow[t]{2}{*}{ Specimens } & \multirow[t]{2}{*}{ Refits } & \multicolumn{4}{|c|}{ Technical stage } & \multirow[t]{2}{*}{ Tech. features } \\
\hline & & & & $\mathrm{CR}$ & PREP & DP & FEC & \\
\hline Beniaia & $5.2 \_1$ & 2 & $\mathrm{R} 2$ & - & - & - & 2 & Ud \\
\hline Serreta & $5.2 \_2$ & 4 & - & - & 3 & 1 & - & Ud Levallois \\
\hline Serreta & $5.2 \_3$ & 2 & - & 1 & 3 & - & - & Core-flake RCL \\
\hline Beniaia & $5.2 \_4$ & 2 & - & 1 & 1 & - & - & Core-flake RCL \\
\hline Serreta & $5.2 \_5$ & 3 & $\begin{array}{l}\text { R3 } \\
-\end{array}$ & $\begin{array}{l}2 \\
1\end{array}$ & - & $\begin{array}{l}- \\
-\end{array}$ & - & Undiagnosed \\
\hline Serreta & $5.2 \_6$ & 2 & - & - & 2 & - & - & $\mathrm{RCL}$ \\
\hline Mariola & $5.2 \_7$ & 3 & - & - & 3 & - & - & RCL \\
\hline Serreta & $5.2 \_8$ & 3 & - & 2 & - & 1 & - & Undiagnosed \\
\hline Mariola & $5.2 \_9$ & 4 & - & 4 & - & - & - & Undiagnosed \\
\hline
\end{tabular}

$R M U$, raw material unit; $T E C H$., technological; $C R$, cortex removal; $P R E P$, preparation of the core; $D P$, debitage products; $F E C$, final exploitation of the core; $R C L$, recurrent centripetal Levallois; $U d$, unidirectional

\section{Dissecting hearth-related micropalimpsests in 4.1 and 5.3}

Regarding the AUs 4.1 and 5.3, all the archaeological record comprised within them has been associated with several higher-resolution units that might respond to single occupations: two in 4.1 (4.1.1 and 4.1.2) and three in 5.3 (5.3.1, 5.3.2 and 5.3.3). All of them present a semicircular-like spatial distribution of the RMU lithic record around the hearths, and have a single combustion structure within (Figs. 8 and 16).

The number of lithic inputs is significantly reduced in these new analytical units. In 4.1 , the lithic assemblage linked to H26 comprises five RMUs, and the one linked to H25 is made up of eight; in 5.3, the lithic assemblages related to H31, H29 and H32 contain four, five and thirteen RMUs, respectively.
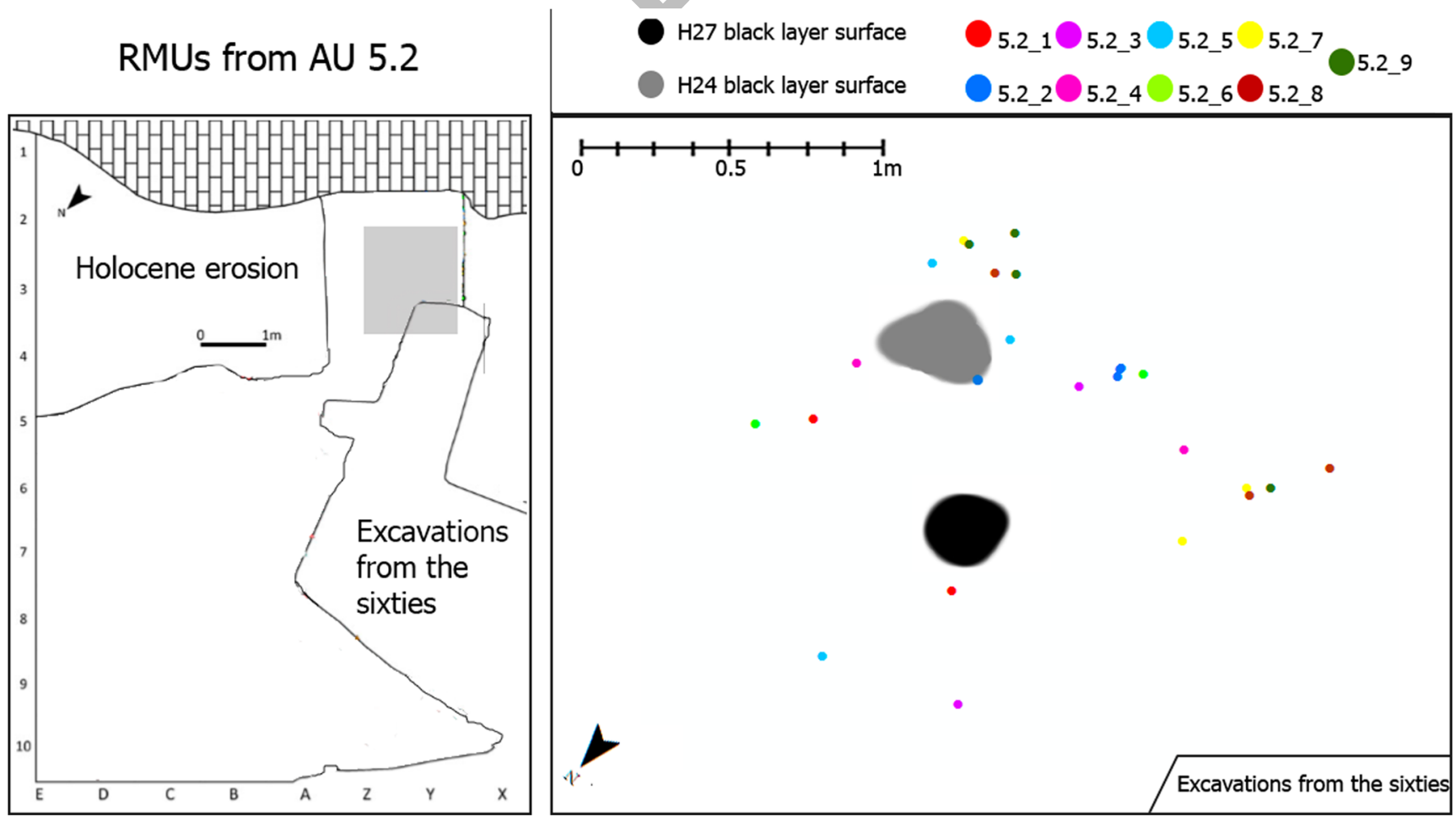

Fig. 12 Map representing the spatial distribution of the RMUs and the hearths belonging to AU 5.2 
Table 7 Technological data from AU 5.3

Archaeostratigraphic unit 5.3

\begin{tabular}{|c|c|c|c|c|c|c|c|c|}
\hline \multirow[t]{2}{*}{ Raw material } & \multirow[t]{2}{*}{ RMU } & \multirow[t]{2}{*}{ Specimens } & \multirow[t]{2}{*}{ Refits } & \multicolumn{4}{|c|}{ Technical stage } & \multirow[t]{2}{*}{ Tech. features } \\
\hline & & & & $\mathrm{CR}$ & PREP & $\mathrm{DP}$ & FEC & \\
\hline Serreta & $5.3 \_1$ & 2 & - & - & 2 & - & - & RCL \\
\hline Serreta & $5.3 \_2$ & 2 & - & - & 2 & - & - & Core-flake RCL \\
\hline Serreta & $5.3 \_3$ & 2 & - & - & 2 & - & - & RCL \\
\hline Serreta & $5.3 \_4$ & 5 & - & - & 4 & - & 1 & RCL \\
\hline Beniaia & $5.3 \_5$ & 2 & - & - & 2 & - & - & RCL \\
\hline Serreta & $5.3 \_6$ & 4 & - & - & 3 & 1 & - & Core-flake RCL (2) and RCL (1) \\
\hline Serreta & $5.3 \_7$ & 2 & - & - & 2 & - & - & RCL \\
\hline Mariola & $5.3 \_8$ & 2 & - & - & 1 & 1 & - & Undiagnosed \\
\hline Mariola & 5.3_9 & 2 & - & - & 2 & - & - & $\mathrm{RCL}$ \\
\hline Font Roja & $5.3_{10}$ & 2 & - & - & 2 & - & - & Up non-L \\
\hline Beniaia & $5.3 \_11$ & 2 & R4 & - & 2 & - & - & Up Levallois? \\
\hline Mariola & ${ }^{5.3}-$ & 3 & - & - & 3 & - & & Discoidal \\
\hline Mariola & $5.3_{-13}$ & 4 & - & 2 & 2 & - & - & RCL \\
\hline Serreta & $5.3_{14}$ & 2 & - & - & - & 2 & - & Undiagnosed \\
\hline Beniaia & $5.3_{-}$ & 3 & - & - & 3 & - & - & RCL \\
\hline Serreta & $5.3_{16}$ & 2 & - & - & 2 & - & - & Up non-L \\
\hline Mariola & $5.3_{17}$ & 4 & - & 3 & - & - & 1 & RCL \\
\hline Mariola & $5.3_{-}$ & 2 & - & & 2 & - & - & RCL \\
\hline Serreta & $5.3_{-}$ & 3 & - & 1 & 3 & - & - & RCL \\
\hline Serreta & $5.3_{20}$ & 2 & - & - & 1 & 1 & - & Undiagnosed \\
\hline Unknown & $5.3_{-}$ & 2 & & - & - & 2 & - & Undiagnosed \\
\hline Unknown & $5.3-$ & 2 & - & 1 & 1 & - & - & Non-L \\
\hline
\end{tabular}

$R M U$, raw material unit; $T E C H$., technological; $C R$, cortex removal; $P R E P$, preparation of the core; $D P$, debitage products; $F E C$, final exploitation of the core; $R C L$, recurrent centripetal Levallois; $U p$, unipolar; non- $L$, non-Levallois

All of these include three types of flint except for 5.3.3, which contains five types (Table 8).

The faunal record from these AUs indicates the presence of more than a single occupation episode. Three cervidae and three equidae in 4.1 and four caprinae, two cervidae and four equidae in 5.3. This volume of individuals and a relatively wide variability of taxa feasibly point to the fact that several occupation episodes are present within these AU contexts.

\section{Hearth as a requirement in 3.2}

This is an interesting case in the frame of this study, since most of the archaeological record from $\mathrm{AU} 3.2$, scattered over almost $32 \mathrm{~m}^{2}$, has not been associated by means of stratigraphic correlation indicating intra-occupational diachrony, since the six RMUs that display temporal markers are exclusively gathered around $\mathrm{H} 23$ and $\mathrm{H} 22$ over a very specific area. The $\mathrm{AU}$ record does not respond to the formation of a single occupation: it comprises two combustion structures and the largest amount of potential single faunal and lithic inputs, and shows the highest degree of taxa variability and raw material diversity.

AU 3.2 is the only recorded example of this: whereas six RMUs have been related to $\mathrm{H} 22$ as a human occupation (named 3.2.1), the remaining RMUs and $\mathrm{H} 23$ have not been connected to defined anthropogenic episodes, but to an indefinite amount 

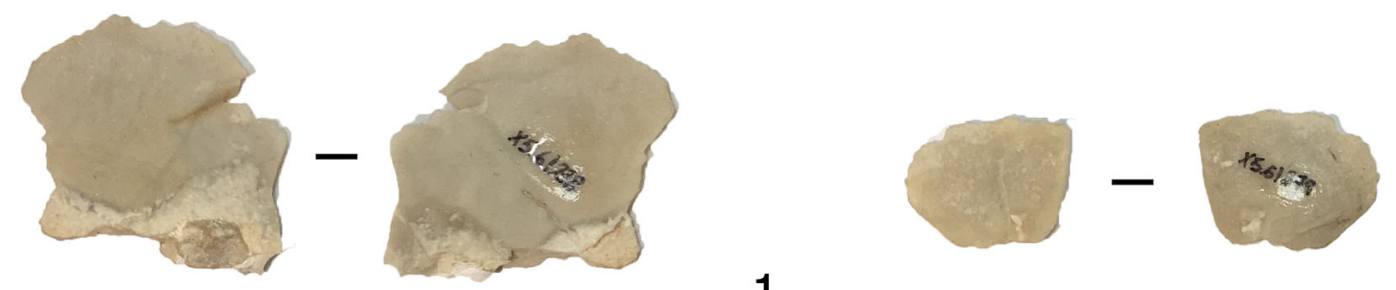

1
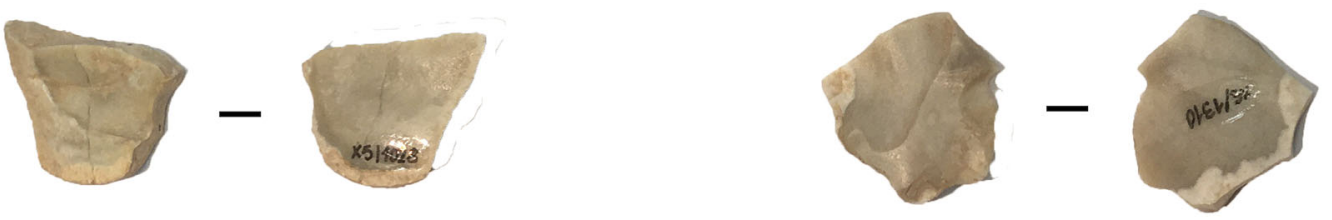

2
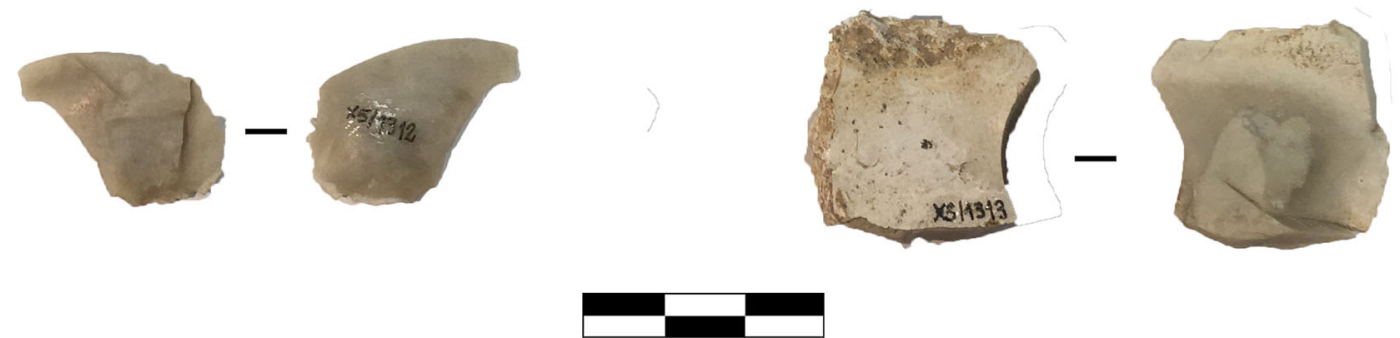

Fig. 13 Specimens comprised within the RMUs 5.2_1 (1), 5.2_2 (2), 5.233 (3), 5.27 (4) and 5.2 (only two out of four specimens) (5). These are five from the nine RMUs belonging to AU 5.2

of deposition events. In this way, 3.2.1 would comprise at least thirteen flint finds from six different RMUs (Fig. 4). All these RMUs possess a fragmentary character, so they do not display the fundamental elements to discern every step of the knapping procedures. Nevertheless, the archaeostratigraphic relations are not enough either to fully differentiate every event from the others or to associate them into an intra-occupational diachronic context. In conclusion, the AU 3.2 does not only show that several and indeterminate anthropogenic deposition events might be comprised in the context of this AU, but also that a part of that non-related record may belong to the recognised one.

\section{Unraveling technical behaviours within the single occupation frame}

Technomorphological analysis of the lithic record was based on the assumption that AUs are high-resolution frameworks from which we could accurately approach technological dynamics. We observed a prevalence of technical procedures geared at recovering convexity or generating edges on debitage surfaces of the cores. We also observed low proportions of full-debitage products, especially if we keep in mind that knapping activities have been recorded within all the AUs. The remainder of the record resulting from other technical procedures, including the final stage of the cores, is evidenced variably and without important differences between them or AUs (Tables 3, 4, 5, 6 and 7).

All the new analytical units share a technological behaviour featured by the predominance of the RCL modality applied on a variety of regional Prebetic raw materials that can be acquired locally within the upper course of the Serpis river and tributaries, mainly in Quaternary alluvial and colluvial deposits and in Oligocene-Aquitanian and Serravallian marine conglomerates (Molina et al. 2010). These characteristics seem to be common within Middle Palaeolithic contexts of the wider geographic region (e.g. Eixea et al. 2011; Fernández et al. 2008; Molina 2016; Molina et al. 2016). Zooming into our single occupation assemblages, we observed further behavioural variability.

These technological observations still hold in light of the assemblages classified here within single occupation episodes. In 4.1.1, 5.3.1 and 5.3.2, the RCL modality is exclusive. In 3.2.1, 4.1.2 and 5.1, this modality, even if it is still predominant, coexists with unipolar non-Levallois procedures recorded solely in the final exploitation stages

Fig. 14 Specimens comprised within the RMUs 5.3_5 (1) and 5.3_13 (2). These are two from the four RMUs belonging to the 5.3.1 occupation episode 

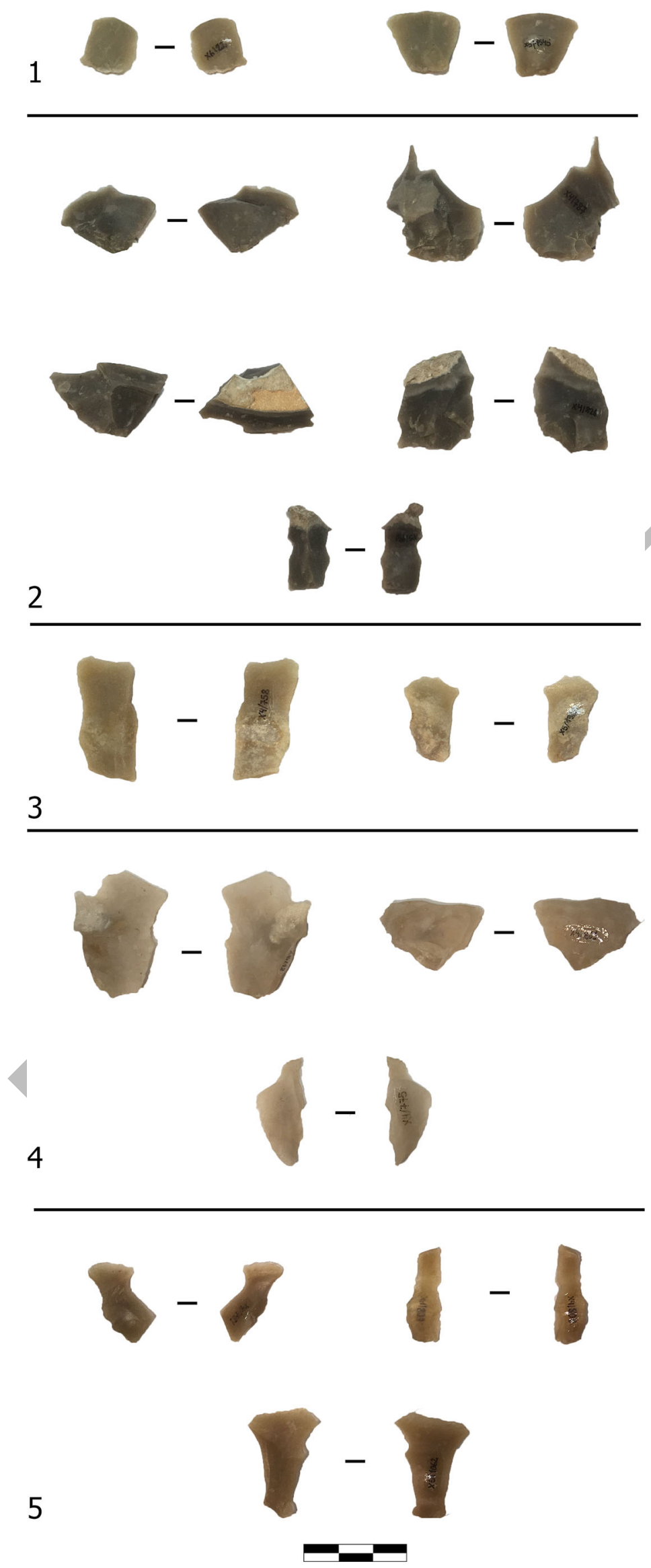

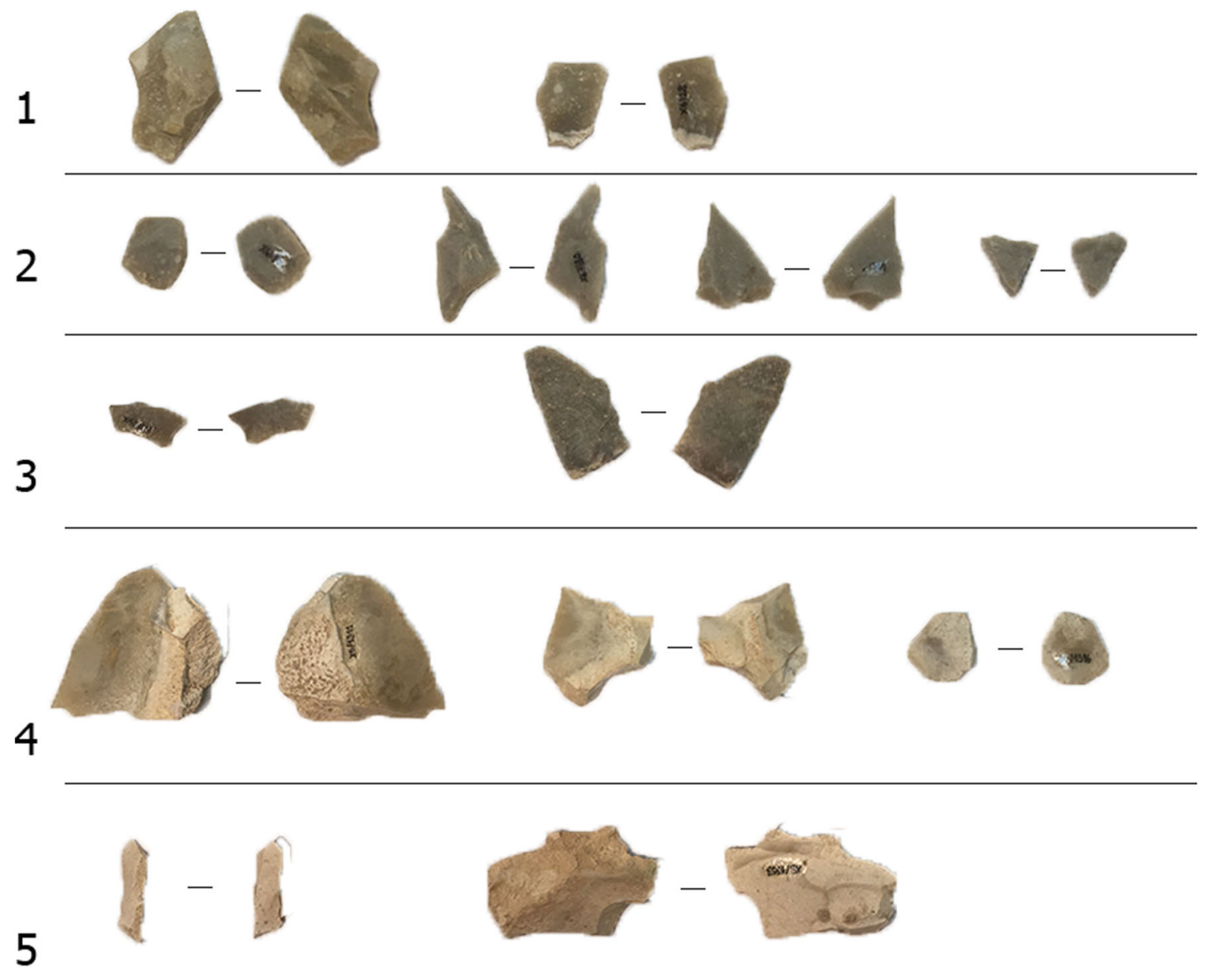

Fig. 15 Specimens comprised within the RMUs 5.3_3 (1), 5.3_4 (2), 5.3_9 (3), 5.3_15 (4) and 5.3_19 (5). These are the five RMUs belonging to the 5.3.2 occupation episode

of three cores. Unit 5.3.3 has to be highlighted due to the fact that it is technologically diverse: RCL, unipolar nonLevallois and discoidal production systems are present in the record (Table 8). AU 3.2 shows a wide degree of technological variability, but the higher-resolution level obtained with 3.2.1 adds a degree of nuance. On the contrary, AU 5.3 shows a RCL predominance among other quantitatively minor strategies, concealing interoccupational variability represented by the exclusive application of RCL in 5.3.1 and 5.3.2, and by the large diversity of procedures comprised in 5.3.3.

In most of these cases, knapping activities are performed using cores obtained from flint pebbles, but others show the additional presence of flake-cores, such as in 4.1.1, 4.1.2 and 5.3.3. These flakes leveraged as cores are exclusively performed on the Serreta flint type, which has an especially optimal concoidal fracture (Machado et al. 2017; Molina et al. 2010), enhancing obtention of larger flakes with ventral convexity, thus making them suitable as cores.

Another sign of technological variability resides in the distinct solutions applied during the stages prior to the abandonment of the cores. The most common procedure involves keeping the same modality from the beginning to the end of the Levallois knapping sequence, maintaining the flat extraction angle. However, in 4.1.1, we have observed that one of the cores displays a more secant final extraction. This has been recorded in other units from El Salt and in a number of other archaeological sites, and is interpreted as a final effort to optimise the raw material mass when it does not permit further exploitation. Occasionally, this technical solution does not consist of a single more secant extraction, but of a series of these, which confers a discoidal shape to the core (e.g. Galván et al. 2009; Moncel et al. 2017; Picin and Vaquero 2016; Ranhorn et al. 2018). The existence of three abandoned 

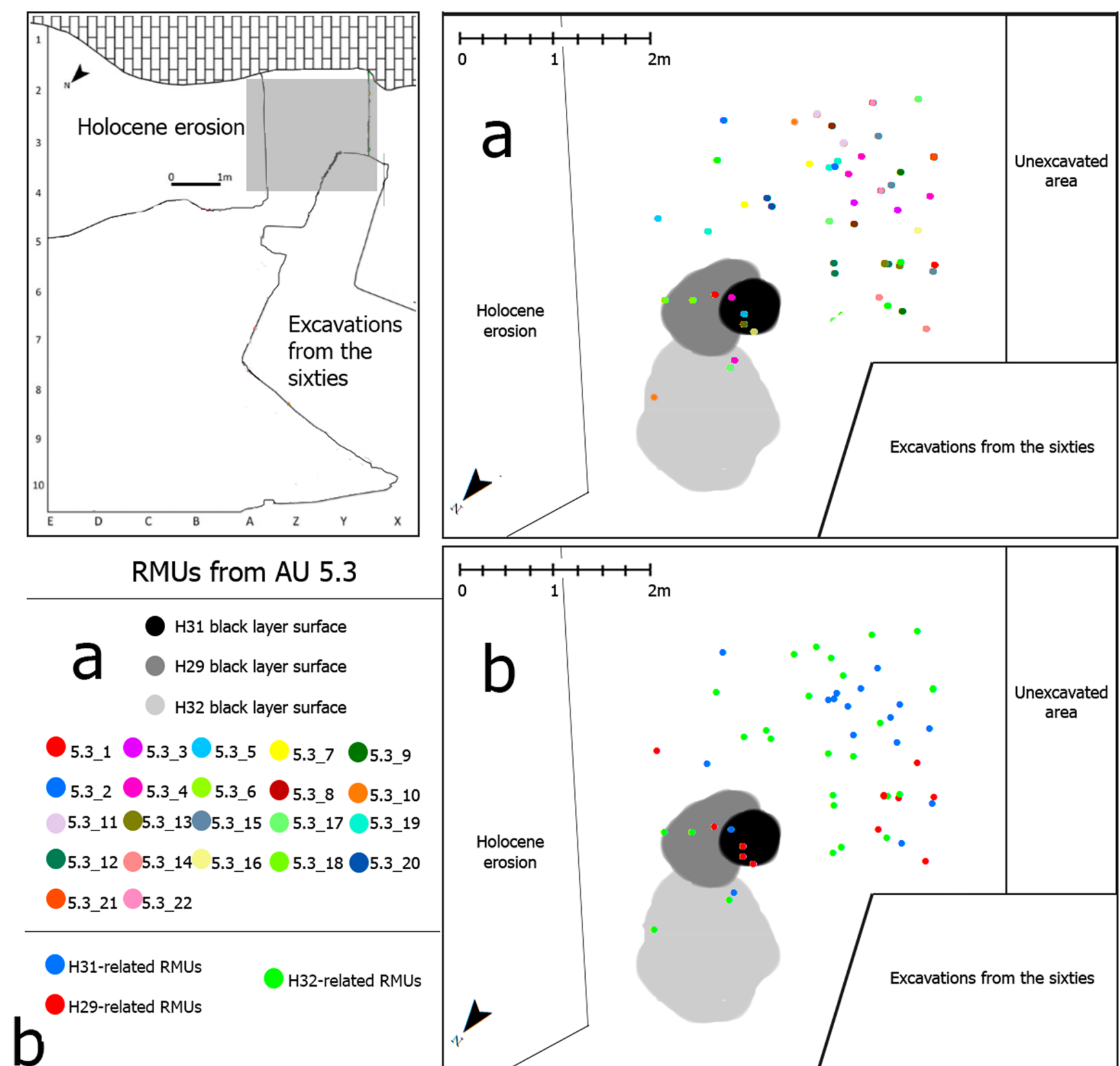

H32-related RMUs

Fig. 16 Specimens comprised within the RMUs 5.3_2 (1), 5.3_6 (2), 5.3_10 (3), 5.3_12 (4) and 5.3_18 (5). These are five from the thirteen RMUs belonging to the 5.3 .3 occupation episode

unipolar non-Levallois cores might be indicating another kind of final solution for Levallois operational sequences. In spite of that, we do not have sufficient supporting evidence and it might alternatively represent the last image of three sequences completely performed using a unipolar non-Levallois procedure.

The last technological feature observed alludes to the material integrity of the lithic assemblage. Broadly, all the lithic record from the AUs shows a fragmentary nature. If we group the RMUs by $\mathrm{AU}$, the represented operational sequences lack the necessary diagnostic elements to discern the progression of all the technical procedures that shaped them. This incompleteness is characterised by a strong presence of blanks utilised for recovering the debitage surface convexity or for shaping the striking platform, followed by the presence of a number of exhausted cores and cortical flakes, and the almost complete absence of debitage products.

Analysing the record from the new analytical unit framework has shown the same fragmentary character (Table 9). Considering each of these units as the closest representation of a single occupation, we infer that the same dynamics of input and export of raw material mass were carried out in all cases. The low proportions of cortical flakes in relation with 


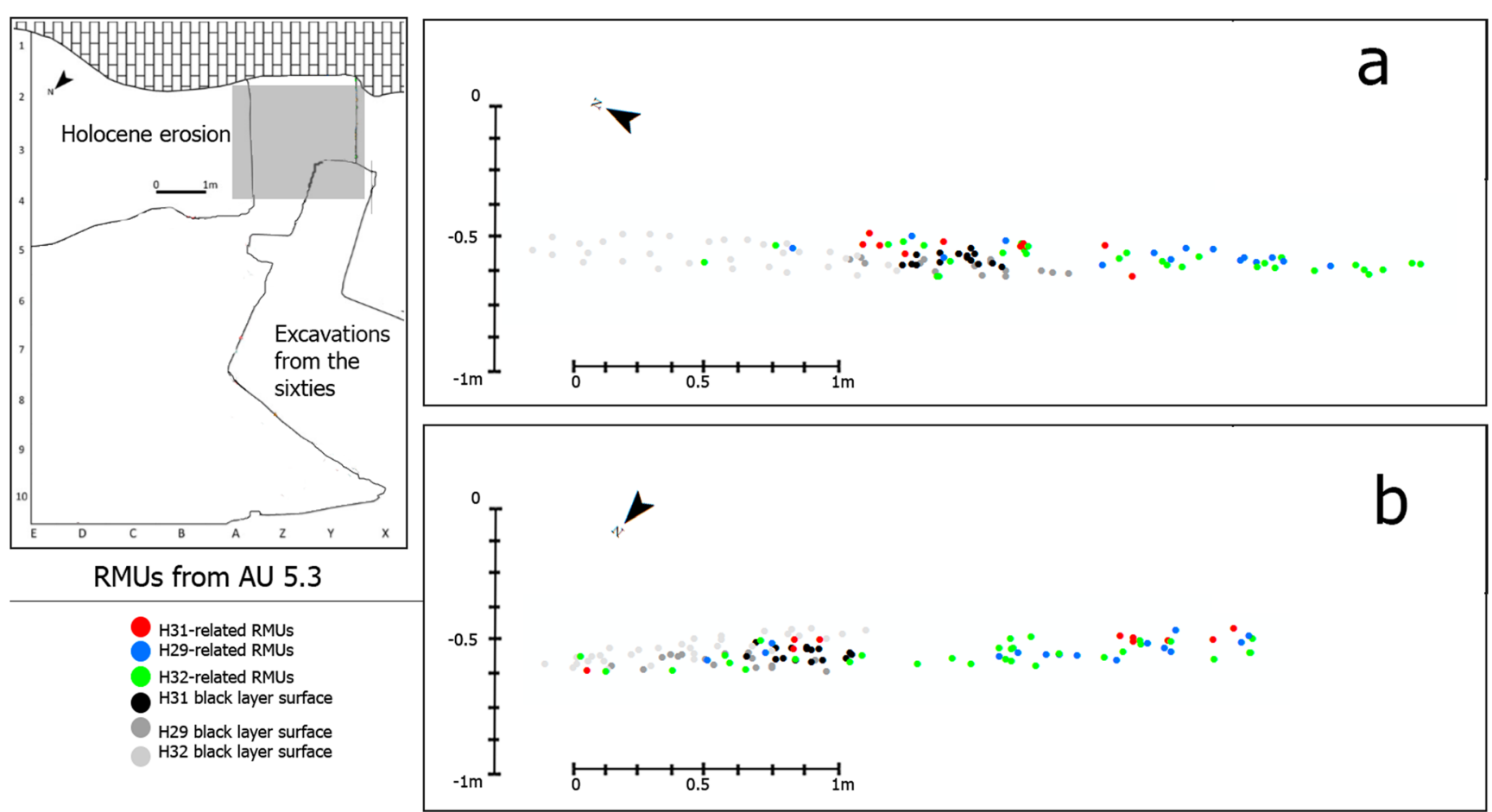

Fig. 17 Maps showing the spatial distribution of the RMUs and the hearths from AU 5.3 (a), and the horizontal relationship between RMUs and hearths (b)

the larger amount of abandoned cores points to the transportation of previously shaped flint masses that are exploited by means of short knapping sequences. These sequences are mainly reflected on the record as a wide number of products resulting from processes of striking platform preparation and recovering of debitage surface convexity.

\section{Approaching behaviours: mobility patterns and technical strategies}

Observing the AUs from the perspective of the micropalimpsest, the archaeostratigraphic analysis of the spatial relationships amongst RMUs and hearths, and the feedback with the main taxonomical features of the faunal record have allowed us to achieve a higher degree of spatiotemporal resolution. These higher-resolution frames corresponding to human occupation episodes have shown two main indicators of site-use and mobility patterning, respectively:

- Even if they may represent incomplete single occupations due to the fact that the excavation area does not cover the whole potentially available space, these activity areas are self-contained and frequently organised as hearth-related assemblages. This suggests an absence of extensive use of the mentioned space, and, on the contrary, a focalised utilisation of more reduced zones. The use of small areas where Palaeolithic groups performed activities has been evidenced through both ethnographic and archaeological approaches (e.g. Binford 1980; Grove 2009; Maher et al. 2016; Vaquero and Pastó 2001).

- The lack of sedimentary structures that reflect hiatus between these new analytical frames and their presence between AUs indicate the existence of recurrent occupation episodes separated by abandonment periods of indeterminate duration, which is broadly pointing to a high-mobility model. This supports several studies carried out in the site (e.g. Leierer et al. 2019; Machado and Pérez 2016; Machado et al. 2017; Vidal 2017).

In turn, the technological conclusions inferred from these new analytical frames are different from those interpreted through the framework displayed by the AU. This becomes especially significant in regard to technological behaviours and technical strategies, since the particular adaptations to environmental resources and responses to distinct needs are developed within short time-spans. It is reflected in the differences between the $\mathrm{AU}$ frameworks and the new ones:

- In terms of technological variability, we shift from the broad frames of the AUs, in which several strategies coexist with the main Levallois production modalities, to the more variable context of the new ones, in which the Levallois conception still predominates, but also does not necessarily coexist with other non-Levallois schemes. 
Table 8 Technological data from the different new analytical frames

New analytical units

\begin{tabular}{|c|c|c|c|c|c|c|c|c|c|}
\hline & \multirow[t]{2}{*}{ Raw material } & \multirow[t]{2}{*}{ RMU } & \multirow[t]{2}{*}{ Specimens } & \multirow[t]{2}{*}{ Refits } & \multicolumn{4}{|c|}{ Technical stage } & \multirow[t]{2}{*}{ Tech. features } \\
\hline & & & & & CR & PREP & DP & FEC & \\
\hline \multirow[t]{6}{*}{3.2 .1} & Font Roja & $3.2-$ & 2 & - & 1 & - & - & 1 & Up non-L \\
\hline & Serreta & $3.2^{22}$ & 3 & - & - & 3 & - & - & $\mathrm{RCL}$ \\
\hline & Beniaia & $3.2-$ & 2 & - & 2 & - & - & - & Undiagnosed \\
\hline & Mariola & $3.2_{25}$ & 2 & - & 2 & - & - & - & Undiagnosed \\
\hline & Serreta & $3.2-$ & 2 & - & - & 2 & - & - & RCL \\
\hline & Beniaia & 3.2 & 2 & - & - & 2 & - & - & $\mathrm{RCL}$ \\
\hline \multirow[t]{5}{*}{ 4.1.1 } & Mariola & $4.1 \_3$ & 2 & - & - & - & - & 2 & RCL with discoidal-like final extraction \\
\hline & Serreta & $4.1 \_4$ & 2 & - & - & 2 & - & - & Core-flake RCL \\
\hline & Mariola & $4.1 \_6$ & 2 & - & - & - & - & 2 & $\mathrm{RCL}$ \\
\hline & Font Roja & $4.1_{10}$ & 2 & - & - & 2 & - & - & Orth Levallois (1) and RCL (1) \\
\hline & Serreta & $4.1 \_11$ & 2 & - & - & 2 & $\angle$ & 1 & $\mathrm{RCL}$ \\
\hline \multirow[t]{8}{*}{4.1 .2} & Serreta & $4.1 \_1$ & 10 & - & 2 & 8 & - & - & RCL \\
\hline & Mariola & $4.1 \_2$ & 2 & - & - & 2 & - & - & RCL \\
\hline & Beniaia & $4.1 \_5$ & 2 & - & - & 2 & - & - & Levallois? \\
\hline & Serreta & $4.1 \_7$ & 2 & - & - & 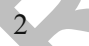 & - & - & Up (1) and core-flake RCL (1) \\
\hline & Serreta & $4.1 \_8$ & 2 & - & 1 & 1 & - & - & Undiagnosed \\
\hline & Serreta & 4.1_9 & 2 & - & 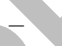 & 2 & - & - & $\mathrm{RCL}$ \\
\hline & Serreta & $4.1_{12}$ & 2 & - & 1 & 1 & - & - & $\mathrm{RCL}$ \\
\hline & Beniaia & $4.1_{13}$ & 2 & - & $\rightarrow$ & 1 & - & 1 & RCL (1) and Up non-L (1) \\
\hline \multirow[t]{4}{*}{5.3 .1} & Beniaia & $5.3 \_5$ & 2 & - & - & 2 & - & - & RCL \\
\hline & Mariola & ${ }^{5.3}-$ & 4 & - & 2 & 2 & - & - & RCL \\
\hline & Serreta & $5.3_{-}$ & 2 & - & - & - & 2 & - & Undiagnosed \\
\hline & Serreta & $5.3_{-}$ & 2 & - & - & 2 & - & - & Undiagnosed \\
\hline \multirow[t]{5}{*}{5.3 .2} & Serreta & $5.3 \_3$ & 2 & - & - & 2 & - & - & $\mathrm{RCL}$ \\
\hline & Serreta & $5.3 \_4$ & 5 & - & - & 4 & - & 1 & RCL \\
\hline & Mariola & 5.3_9 & 2 & - & - & 2 & - & - & $\mathrm{RCL}$ \\
\hline & Beniaia & $5.3_{-}$ & 3 & - & - & 3 & - & - & RCL \\
\hline & Serreta & $5.3_{19}$ & 3 & - & - & 3 & - & - & $\mathrm{RCL}$ \\
\hline \multirow[t]{8}{*}{5.3 .3} & Serreta & $5.3 \_1$ & 2 & - & - & 2 & - & - & RCL \\
\hline & Serreta & $5.3 \_2$ & 2 & - & - & 2 & - & - & Core-flake RCL \\
\hline & Serreta & $5.3 \_6$ & 4 & - & - & 3 & 1 & - & Core-flake RCL \\
\hline & Serreta & $5.3 \_7$ & 2 & - & - & 2 & - & - & RCL \\
\hline & Mariola & $5.3 \_8$ & 2 & - & - & 1 & 1 & - & Undiagnosed \\
\hline & Font Roja & $5.3_{10}$ & 2 & - & - & 2 & - & - & Up non-L \\
\hline & Beniaia & $5.3 \_11$ & 2 & $\mathrm{R} 4$ & - & 2 & - & - & Ud Levallois? \\
\hline & Mariola & $5.3_{12}$ & 3 & 1 & - & - & 2 & - & Discoidal \\
\hline
\end{tabular}


Table 8 (continued)

New analytical units

\begin{tabular}{|c|c|c|c|c|c|c|c|c|}
\hline \multirow{3}{*}{$\begin{array}{l}\text { Raw material } \\
\text { Mariola }\end{array}$} & \multirow{3}{*}{$\begin{array}{c}\text { RMU } \\
5.3_{\overline{17}}\end{array}$} & \multirow{3}{*}{$\begin{array}{l}\text { Specimens } \\
4\end{array}$} & \multirow{3}{*}{$\begin{array}{l}\text { Refits } \\
-\end{array}$} & \multicolumn{4}{|c|}{ Technical stage } & \multirow{3}{*}{$\begin{array}{l}\text { Tech. features } \\
\text { RCL }\end{array}$} \\
\hline & & & & \multirow{2}{*}{$\begin{array}{l}-\mathrm{CR} \\
3\end{array}$} & \multirow{2}{*}{$\begin{array}{l}\text { PREP } \\
-\end{array}$} & \multirow{2}{*}{$\begin{array}{l}\text { DP } \\
-\end{array}$} & \multirow{2}{*}{$\begin{array}{l}\text { FEC } \\
1\end{array}$} & \\
\hline & & & & & & & & \\
\hline Mariola & ${ }^{5.3}$ & 2 & - & - & 2 & - & - & RCL \\
\hline Serreta & $5.3_{20}$ & 2 & - & - & 1 & 1 & - & Undiagnosed \\
\hline Unknown & $5.3_{21}$ & 2 & - & - & - & 2 & - & Undiagnosed \\
\hline Unknown & $5.3_{22}$ & 2 & - & 1 & 1 & - & - & Non-L \\
\hline
\end{tabular}

$R M U$, raw material unit; $T E C H$., technological; $C R$, cortex removal; $P R E P$, preparation of the core; $D P$, debitage products; $F E C$, final exploitation of the core; $R C L$, recurrent centripetal Levallois; orth, orthogonal; $U d$, unidirectional

- In relation to flint types, the record of the new frameworks points to lower degree of diversity: Serreta and Mariola are still the most common ones, but the presence of other minor types, such as Polop, Font Roja and Beniaia, is not as high as if inferring it from the AUs.

- Regarding the volume of the lithic record, the new analytical frames include lesser amounts of lithic material produced by each intra-occupational series of knapping activities. This might be related to the short timeframe during which the occupation episode occurs.

Additionally, the export of lithic material from the site after knapping activities has been evidenced at the site. The almost complete absence of full-debitage tools and the high presence of core-shaping products might be indicating specific knapping processes performed during short time-spans. Other technological studies on this matter have pointed to a link between the lack of lithic material and hunter-gatherer mobility patterns (e.g. Davis and Willis 2011; Morrow 1996; Nielsen 2017; Peresani et al. 2015; Takakura 2018; Terradillos et al. 2017). The assumption is that Palaeolithic contexts showing evidence of knapping activity and incomplete operational sequences within the record are conditioned by short-span settlement dynamics and a respective high degree of mobility. In this sense, the transport of cores previously managed and prepared to be leveraged, the presence of short operational sequences focusing on debitage products and the absence of the latter might indicate that these human groups were carrying out specific and relatively quick knapping activities within the frame of short-term occupations.

In relation to this, the manufacture of the so-called curated and expedient lithic technologies (cf. Binford 1977, 1978, 1989) has also been related to hunter-gatherer group mobility, where curated technologies have been associated with distant and scarce raw material and thus to high mobility patterning. Here, we have observed predominance of curated

Table 9 Quantitative data of technique-related aspects of the lithic record from both AUs and new analytical units

\begin{tabular}{|c|c|c|c|c|c|c|c|c|c|c|c|c|c|c|c|c|c|}
\hline \multirow[t]{2}{*}{$\mathrm{AU}$} & \multicolumn{8}{|c|}{ Technical stage } & \multicolumn{8}{|c|}{ Technical stage } & \multirow[t]{2}{*}{ New analytical unit } \\
\hline & $\mathrm{CR}$ & $\%$ & PREP & $\%$ & DP & $\%$ & FEC & $\%$ & $\mathrm{CR}$ & $\%$ & PREP & $\%$ & DP & $\%$ & FEC & $\%$ & \\
\hline 3.2 & 15 & 18.3 & 48 & 58.6 & 3 & 3.6 & 16 & 19.5 & 5 & 39.5 & 7 & 53.7 & 0 & 0.0 & 1 & 7.7 & 3.2 .1 \\
\hline \multirow[t]{2}{*}{4.1} & 4 & 11.8 & 25 & 73.5 & 0 & 0.0 & 5 & 14.7 & 0 & 0.0 & 6 & 75.0 & 0 & 0.0 & 2 & 25.0 & 4.1.1 \\
\hline & & & & & & & & & 4 & 15.4 & 21 & 80.8 & 0 & 0.0 & 1 & 3.8 & 4.1.2 \\
\hline 5.1 & 3 & 15.8 & 15 & 78.9 & 0 & 0.0 & 1 & 5.3 & - & - & - & - & - & - & - & - & - \\
\hline 5.2 & 11 & 39.4 & 13 & 46.4 & 2 & 7.1 & 2 & 7.1 & - & - & - & - & - & - & - & - & - \\
\hline \multirow[t]{3}{*}{5.3} & 6 & 10.7 & 41 & 73.2 & 7 & 12.5 & 2 & 3.6 & 2 & 18.2 & 6 & 54.5 & 2 & 18.2 & 1 & 9.1 & 5.3 .1 \\
\hline & & & & & & & & & 0 & 0.0 & 14 & 93.3 & 0 & 0.0 & 1 & 6.7 & 5.3 .2 \\
\hline & & & & & & & & & 4 & 13.4 & 18 & 60.0 & 7 & 23.3 & 1 & 3.3 & 5.3 .3 \\
\hline Total & 39 & 17.8 & 142 & 64.8 & 12 & 5.5 & 26 & 11.9 & 15 & 14.6 & 72 & 70.0 & 9 & 8.7 & 7 & 6.7 & Total \\
\hline
\end{tabular}

$A U$, archaeostratigraphic unit; $C R$, cortex removal; $P R E P$, preparation of the core; $D P$, debitage production; $F E C$, final exploitation of the core 
organisation, since RCL modality is the most common in almost all the new analytical units, yet raw material is accessible and abundant along the courses of Serpis, Barxell and Polop rivers, as well as in several flint outcropping areas over the Mariola mountain range. Nevertheless, although raw material is more affordable in terms of effort spent within the fluvial courses, the pebbles that can be acquired there are small-sized and might include internal fractures and limestone and quartzite inclusions that are counter-productive for knapping (cf. Molina et al. 2010, 2016).

These characteristics of the flint nodules may be in relation with the proposal of curated organisation of the cores as a response to a high degree of mobility within a geographic context where quality raw material is scarce or where the outcropping areas are separated by long distances (e.g. Bleed 1986; Bousman 1993; Shott 1996; Vaquero 2012; Vaquero and Romagnoli 2018; Wallace and Shea 2006). This matter requires in-depth qualitative analysis of the raw material groups and their connection to the recorded knapping strategies.

\section{Conclusions}

In this study, we have shown that it is in archaeostratigraphic relationships between the elements of the archaeological record that we can group apparently synchronous or intraoccupationally diachronic events within the single occupation framework, as it has been done by many similar approaches in previous archaeostratigraphic works. Therefore, we can interpret the existence of intra-occupational (not necessarily synchronous, but occurring within a single occupation episode) or inter-occupational diachrony by dissecting micropalimpsest using archaeostratigraphy.

With the resulting single occupation-related assemblages, we can approach even further technical behaviours possibly associated to settlement dynamics, such as the temporal spanning of the occupations, the productivity of the knapping sequences and the activities, the provisioning and management of raw materials, the coexistence of distinct technological strategies, technical solutions and subsistence responses, or the mobility patterning.

Finally, we consider that micropalimpsest dissection is necessary to approach behavioural processes occurring within a human time-scale. Always from an interdisciplinary perspective, micropalimpsest dissection and the resulting identification of single occupation episodes hold the key for characterising and interpreting anthropogenic lithic record formation processes.

Acknowledgements We thank the members of the team of El Salt for their field and post-excavation work, and Museu Arqueològic Municipal Camil Visedo Molto d'Alcoi and the Alcoian town hall for their support.
We also thank the eighteenth International Union of Prehistoric and Protohistoric Sciences (IUPPS) congress organisation, and the organisers of the session named Is "Neanderthal behaviour" a useful concept?: multiscalar approaches to the behavioural diversity of Middle Palaeolithic Neanderthal populations (XVI-7) for allowing us to present this work within it and publish it in this volume. We are thankful to Leopoldo J. Pérez for his support on the archaeozoological questions, to Sara M. Magee for her suggestions and corrections on English writing, to Rory Connolly for his comments during the writing of this paper, and to Santiago Sossa and Mariel Bencomo for their logistical assistance to this study. Additionally, we would like to thank the anonymous reviewers who helped improve the previous versions of this paper with their ideas.

Funding information Archaeological excavations at El Salt rockshelter are funded by the Spanish central government through the project called Neandertales en la montaña alicantina: un enfoque multianalítico (MEC-FEDER HAR2015-68321-P), and by the Valencian autonomous government through public research funding (DOGV P-0300900-H). One of the authors (AM) is also funded by Universitat d'Alacant through a university faculty formation grant (UAFPU 2018-049).

\section{References}

Adler DS, Prindiville TJ, Conard NJ (2003) Patterns of spatial organization and land use during the Eemian interglacial in the Rhineland: new data from Wallertheim, Germany. Eurasian Prehist 1(2):25-78

Albert R, Berna F, Goldberg P (2012) Insights on Neanderthal fire use at Kebara Cave (Israel) through high resolution study of prehistoric combustion features: evidence from phytoliths and thin sections. Quat Int 247:278-293. https://doi.org/10.1016/j.quaint.2010.10.016

Audouze F, Enloe JG (1997) High resolution archaeology at Verberie: limits and interpretations. World Archaeol 29(2):195-207

Baena J, Moncel MH, Cuartero F, Chacón MG, Rubio D (2017) Late Middle Pleistocene genesis of Neanderthal technology in western Europe: the case of Payre site (south-east France). Quat Int 436(A): 212-238. https://doi.org/10.1016/j.quaint.2014.08.031

Baena J, Torres C, Sharon G (2018) Life history of a large flake biface. Quat Sci Rev 190:123-136. https://doi.org/10.1016/j.quascirev. 2018.04.015

Binford LR (1977) Forty-seven trips: a case study in the character of archaeological formation processes. In: Wright RV (ed) Stone tools as cultural markers: change, evolution and complexity. Australian Institute of Aboriginal Studies, Acton, pp 24-36

Binford LR (1978) Organization and formation processes: looking at curated technologies. J Anthropol Res 35(3):255-273

Binford LR (1980) Willow smoke and dogs' tails: hunter-gatherer settlement systems and archaeological site formation. Am Antiq 45(1):4 20. https://doi.org/10.2307/279653

Binford LR (1989) Debating archaeology. Academic Press, New York

Bleed P (1986) The optimal design of hunting weapons: maintainability or reliability. Am Antiq 51(4):737-747. https://doi.org/10.2307/ 280862

Bourguignon L, Blaser F, Ríos J, Pradet L, Sellami F, Guibert P (2008) L'occupation moustérienne de la Doline de Cantalouette II (Creysse, Dordogne): spécificités technologiques et économiques, premiers résultats d'une analyse intégrée. In: Jaubert J, Bordes JG, Ortega I (eds) Les sociétés du Paléolithique dans un Grand Sud-Ouest de la France: nouveaux gisements, noveaux résultats, nouvelles méthodes. Société Préhistorique Française, Nanterre, pp 133-150

Bourguignon L, Faivre JP, Turq A (2004) Ramification des chaînes opératoires: une spécificité du Moustérien? Paleo 16:37-48 
Bousman CB (1993) Hunter-gatherer adaptations, economic risk and tool design. Lithic Technol 18:59-86. https://doi.org/10.1080/01977261. 1993.11720897

Carrancho A, Villalaín JJ, Vallverdú J, Carbonell E (2016) Is it possible to identify temporal differences among combustion features in Middle Palaeolithic palimpsests? The archaeomagnetic evidence: a case study from level $\mathrm{O}$ at the Abric Romaní rock-shelter (Capellades, Spain). Quat Int 417:39-50. https://doi.org/10.1016/j.quaint.2015. 12.083

Casanova J, Mora R, Martínez J, De la Torre I (2008) Diversidad y continuidad de los sistemas técnicos del Paleolítico medio en los Pirineos sur-orientales. Treb Arqueol 14:27-63

Chacón MG, Bargalló A, Gabucio MJ, Rivals F, Vaquero M (2015) Neanderthal behaviors from a spatio-temporal perspective: an interdisciplinary approach to interpret archaeological assemblages. In: Conard NJ, Delagnes A (eds) Settlement dynamics of the Middle Paleolithic and Middle Stone Age Iv. Kerns Verlag, Tübingen, pp 253-294

Conard NJ (2001) Advances and problems in the study of Paleolithic settlement systems. In: Conard NJ (ed) Settlement dynamics of the Middle Paleolithic and Middle Stone Age IV. Kerns Verlag, Tübingen, pp 7-20

Conard NJ, Adler DS (1997) Lithic reduction and hominid behavior in the Middle Palaeolithic of the Rhineland. J Anthropol Res 53:147176

Cuartero F, Alcaraz M, López M, Carrión E, Baena J (2015) Recycling economy in the Mousterian of the Iberian peninsula: the case study of El Esquilleu. Quat Int 361:113-130. https://doi.org/10.1016/j. quaint.2014.11.059

Davis LG, Willis SC (2011) Technology, mobility, and adaptation among early foragers of the southern northwest coast: the view from Indian Sands, southern Oregon coast, USA. In: Bicho NF, Haws J, Davis LG (eds) Trekking the shore: interdisciplinary contributions to archaeology. Springer Business+Media, New York, pp 137-160

Dorta RJ, Hernández CM, Molina FJ, Galván B (2010) La alteración térmica en los sílex de los valles alcoyanos (Alicante, España). Una aproximación desde la arqueología experimental en contextos del Paleolítico medio: El Salt. Recer Mus Alcoi 19:33-64

Eixea A, Villaverde V, Zilhão J (2011) Aproximación al aprovisionamiento de materias primas líticas en el yacimiento del Paleolítico medio del Abrigo de la Quebrada (Chelva, Valencia). Trab Prehist 68(1):65-78. https://doi.org/10.3989/tp.2011.11059

Fernández J, Barciela V, Blasco R, Cuartero F, Sañudo P (2008) El Paleolítico medio en el territorio valenciano y la variabilidad tecno-económica de la Cova del Bolomor. Treb Arqueol 14:141169

Gabucio MJ, Cáceres I, Rodríguez A, Rosell J, Saladié P (2014) A wildcat (Felis silvestris) butchered by Neanderthals in level O of the Abric Romaní site (Capellades, Barcelona, Spain). Quat Int 326-327:307318. https://doi.org/10.1016/j.quaint.2013.10.051

Gabucio MJ, Cáceres I, Rivals F, Bargalló A, Rosell J, Saladié P, Vallverdú J, Vaquero M, Carbonell E (2016) Unraveling a Neanderthal palimpsest from a zooarchaeological and taphonomic perspective. Archaeol Anthropol Sci 10(1):197-222. https://doi.org/ 10.1007/s12520-016-0343-y

Galván B, Hernández CM, Francisco MI, Molina FJ, Tarriño A (2009) La producción lítica del Abric del Pastor (Alcoy, Alicante): un ejemplo de la variabilidad musteriense. Tabona 17:11-61

Galván B, Hernández CM, Mallol C, Machado J, Sistiaga A, Molina FJ, Pérez LJ, Afonso R, Garralda MD, Mercier N, Morales JV, Sanchís A, Tarriño A, Gómez JA, Rodríguez À, Abreu I, Vidal P (2014a) El Salt: the last Neanderthals of the Alicante mountains (Alcoy, Spain). In: Sala R, Carbonell E, Bermúdez de Castro JM, Arsuaga JL (eds) Pleistocene and Holocene hunter-gatherers in Iberia and the Gibraltar strait: the current archaeological record. Servicio de Publicaciones de la Universidad de Burgos, Burgos, pp 380-388
Galván B, Hernández CM, Mallol C, Mercier N, Sistiaga A, Soler V (2014b) New evidence of early Neanderthal disappearance in the Iberian peninsula. J Hum Evol 75:16-27. https://doi.org/10.1016/j. jhevol.2014.06.002

Glauberman PJ (2016) Middle Palaeolithic land use in Dutch and Belgian Limburg: integrating data from surface sites. Quat Int 411:198-215. https://doi.org/10.1016/j.quaint.2015.06.033

Goldberg P, Berna F (2010) Micromorphology and context. Quat Int 214(1):56-62. https://doi.org/10.1016/j.quaint.2009.10.023

Grove M (2009) Hunter-gatherer movement patterns: causes and constraints. J Anthropol Archaeol 28(2):222-233. https://doi.org/10. 1016/j.jaa.2009.01.003

Henry DO (2012) The palimpsest problem, hearth pattern analysis, and Middle Paleolithic site structure. Quat Int 247:246-266. https://doi. org/10.1016/j.quaint.2010.10.013

Higham TF (2013) Hunter-gatherers in Southeast Asia: from prehistory to the present. Hum Biol 85(1-3):21-44. https://doi.org/10.3378/027. 085.0302

Holdaway SJ, Fanning P, Rhodes E (2008) Assemblage accumulation as time-dependent process in the arid zone of western New South Wales, Australia. In: Holdaway SJ, Wandsnider L (eds) Time in archaeology: time perspectivism revisited. University of Utah Press, Salt Lake City, pp 110-133

Holdaway SJ, Wandsnider L (2006) Temporal scales and archaeological landscapes from the eastern desert of Australia and intermontane North America. In: Lock G, Molyneaux B (eds) Confronting scale in archaeology: issues of theory and practice. Springer, New York, pp 183-202

Holdaway SJ, Wandsnider L (2008) Time in archaeology: an introduction. In: Holdaway SJ, Wandsnider L (eds) Time in archaeology: time perspectivism revisited. University of Utah Press, Salt Lake City, pp 1-12

Hudson MJ, Aoyama M (2009) Hunter-gatherers and the behavioural ecology of human occupation. Can J Occup Ther 76(1):48-55. https://doi.org/10.1177/000841740907600113

Knutsson H, Knutsson K, Taipale N, Tallavaara M, Darmark K (2015) How shattered flakes were used: micro-wear analysis of quartz flake fragments. J Archaeol Sci Rep 2:517-531. https://doi.org/10.1016/j. jasrep.2015.04.008

Lazuén T, Delagnes A (2014) Lithic tool management in the early Middle Paleolithic: an integrated techno-functional approach applied to Le Pucheil-type production (Le Pucheil, northwestern France). J Archaeol Sci 52:337-353. https://doi.org/10.1016/j.jas.2014.08.029

Leierer L, Jambrina M, Herrera AV, Connolly R, Hernández CM, Galván B, Mallol C (2019) Insights into the timing, intensity and natural setting of Neanderthal occupation from the geoarchaeological study of combustion structures: a micromorphological and biomarker investigation of El Salt, unit Xb, Alcoy, Spain. PLoS One 14(4). https://doi.org/10.13717/journal.pone.0214955

Lemorini C, Bourguignon L, Zupancich A, Gopher A, Barkai R (2016) A scraper's life history: morpho-techno-functional and use-wear analysis of Quina and demi-Quina scrapers from Qesem Cave, Israel. Quat Int 398:86-93. https://doi.org/10.1016/j.quaint.2015.05.013

López E, Bargalló A, Lombera A, Mosquera M, Ollé M, Rodríguez XP (2017) Quartz and quartzite refits at Gran Dolina (Sierra de Atapuerca, Burgos): connecting lithic artefacts in the Middle Pleistocene unit of TD10.1. Quat Int 433(A):85-102. https://doi. org/10.1016/j.quaint.2015.09.026

Machado J, Hernández CM, Mallol C, Galván B (2013) Lithic production, site formation, and Middle Palaeolithic palimpsest analysis: in search of human occupation episodes at Abric del Pastor stratigraphic unit IV (Alicante, Spain). J Archaeol Sci 40:2254-2273. https:// doi.org/10.1016/j.jas.2013.01.002

Machado J, Mallol C, Hernández CM (2015) Insights into Eurasian Middle Paleolithic settlement dynamics: the palimpsest problem. In: Conard NJ, Delagnes A (eds) Settlement dynamics of the 
Middle Paleolithic and Middle Stone Age IV. Kerns Verlag, Tübingen, pp 361-382

Machado J, Mayor A, Hernández CM, Galván B (2019) Lithic refitting and the analysis of Middle Palaeolithic settlement dynamics: a hightemporal resolution example from El Pastor rock shelter (eastern Iberia). Archaeol Anthropol Sci 11(9):4539-4554. https://doi.org/ 10.1007/s12520-019-00859-8

Machado J, Molina FJ, Hernández CM, Tarriño A, Galván B (2017) Using lithic assemblage formation to approach Middle Palaeolithic settlement dynamics: El Salt stratigraphic unit X (Alicante, Spain). Archaeol Anthropol Sci 9(8):1715-1743. https://doi.org/10.1007/ s12520-016-0318-z

Machado J, Pérez LJ (2016) Temporal frameworks to approach human behavior concealed in Middle Palaeolithic palimpsests: a highresolution example from El Salt stratigraphic unit X (Alicante, Spain). Quat Int 417:66-81. https://doi.org/10.1016/j.quaint.2015. 11.050

Maher LA, Macdonald DA, Allentuck A, Martin L, Spyrou A, Jones MD (2016) Occupying wide open space?: late Pleistocene huntergatherer activities in the eastern Levant. Quat Int 396:79-94. https://doi.org/10.1016/j.quaint.2015.07.054

Mallol C, Hernández CM (2016) Advances in palimpsest dissection. Quat Int 417:1-2. https://doi.org/10.1016/j.quaint.2016.09.021

Mallol C, Hernández CM, Cabanes D, Machado J, Sistiaga A, Pérez LJ, Galván B (2013a) Human actions performed on simple combustion structures: an experimental approach to the study of Middle Palaeolithic fire. Quat Int 315:3-15. https://doi.org/10.1016/j. quaint.2013.04.009

Mallol C, Hernández CM, Cabanes D, Sistiaga A, Machado J, Rodríguez À, Pérez LJ, Galván B (2013b) The black layer of Middle Palaeolithic combustion structures: interpretation and archaeostratigraphic implications. J Archaeol Sci 40:2515-2537. https://doi.org/10.1016/j.jas.2012.09.017

Mallol C, Hernández CM, Machado J (2012) The significance of stratigraphic discontinuities in Iberian Middle-to-Upper Palaeolithic transitional sites. Quat Int 275:4-13. https://doi.org/10.1016/j.quaint. 2011.07.026

Mallol C, Mentzer S (2015) Contacts under the lens: perspectives on the role of microstratigraphy in archaeological research. Archaeol Anthropol Sci 9(8):1645-1669. https://doi.org/10.1007/s12520015-0288-6

Martínez J, De la Torre I, Mora R, Casanova J (2010) Technical variability changes in the pattern of settlement at Roca dels Bous (southeastern pre-Pyrenees, Spain). In: Conard NJ, Delagnes A (eds) Settlement dynamics of the Middle Paleolithic and Middle Stone Age III. Kerns Verlag, Tübingen, pp 485-507

Martínez J, Mora R, Roy M, Benito A (2016) From site formation processes to human behavior: towards a constructive approach to depict palimpsests in Roca dels Bous. Quat Int 417:82-93. https://doi.org/ 10.1016/j.quaint.2015.09.038

Modolo M, Rosell J (2016) Reconstructing occupational models: bone refits in level I of Abric Romaní. Quat Int 435(A):180-194. https:// doi.org/10.1016/j.quaint.2015.12.098

Molina FJ (2016) Estudio geoarqueológico de entornos sedimentarios fluvio-lacustres y endorreicos con industrias del Paleolítico medio en el norte de la provincia de Alicante (España). Recer Mus Alcoi 25:7-30

Molina FJ, Tarriño A, Galván B, Hernández CM (2010) Áreas de aprovisionamiento de sílex en el Paleolítico medio en torno al Abric del Pastor (Alcoi, Alicante): estudio macroscópico de la producción lítica de la colección Brotons. Recer Mus Alcoi 19:6580

Molina FJ (2015) El sílex del Prebético y cuencas neógenas en Alicante y sur de Valencia: su caracterización y estudio aplicado al Paleolítico medio. Servei de Publicacions de la Universitat d'Alacant, Sant Vicent del Raspeig
Molina FJ, Tarriño A, Galván B, Hernández CM (2016) El sílex del Prebético de Alicante: tipos, variabilidad y áreas de captación y talla del Pleistoceno. Cuad Prehist Arqueol Univ Granada 26:283-311

Moncel MH, Pleurdeau D, Pinhasi R, Yeshurun R, Agapishvili T, Chevalier T, Lebourdonnec FX, Poupeau G, Nomade S, Jennings R, Higham TF, Tushubramishvili N, Lordkipanidze D (2017) The Middle Palaeolithic record of Georgia: a synthesis of the technological, economic and palaeoanthropological aspects. Anthropologie 53(1-2):93-125

Morrow TM (1996) Lithic refitting and archaeological site formation processes: a case study from the Twin Ditch site, Greene county, Illinois. In: Odell GH (ed) Stone tools: theoretical insights into human prehistory. Springer, New York, pp 345-376

Nerudová Z, Neruda P (2017) Technology of Moravian early Szeletian leaf point shaping: a case study of refittings from Moravský Krumlov IV open-air site (Czech Republic). Quat Int 428(A):91108. https://doi.org/10.1016/j.quaint.2015.09.065

Nielsen SV (2017) Long blades and phantom cores: a case of longdistance stone tool refitting (southern Norway). Lithic Technol 42(1):24-34. https://doi.org/10.1080/01977261.2016.1268994

Ortiz I, Baena J (2017) Did stones speak about people? Flint catchment and Neanderthal behavior from area 3 (Cañaveral, Madrid-Spain). Quat Int 435(A):144-163. https://doi.org/10.1016/j.quaint.2016.01. 019

Peresani M, Boldrin M, Pasetti P (2015) Assessing the exploitation of double patinated artifacts from the late Mousterian: implications for lithic economy and human mobility in northern Italy. Quat Int 361: 238-250. https://doi.org/10.1016/j.quaint.2014.10.058

Pérez LJ, Machado J, Hernández CM, Morales JV, Brugal JP, Galván B (2015) Arqueozoología y arqueoestratigrafía del yacimiento de El Salt (Alcoi, Alicante): contribución metodológica para el análisis del registro faunístico contenido en palimpsestos arqueológicos del Paleolítico medio. In: Sanchís A, Pascual JL (eds) Preses petites i grups humans en el passat. Servei de Publicacions de la Universitat de València, València, pp 223-244

Pérez LJ, Sanchís A, Hernández CM, Galván B, Sala R, Mallol C (2017) Hearths and bones: an experimental study to explore temporality in archaeological contexts based on taphonomical changes in burnt bones. J Archaeol Sci Rep 11:287-309. https://doi.org/10.1016/j. jasrep.2016.11.036

Pérez LJ, Machado J, Sanchís A, Hernández CM, Mallol C, Galván B (2019) A high-temporal resolution zooarchaeological approach to Neanderthal subsistence strategies on the south-eastern Iberian peninsula: El Salt stratigraphic unit Xa (Alicante, Spain) . Book chapter, submitted. Springer nature, Cham

Picin A, Vaquero M (2016) Flake productivity in the Levallois recurrent centripetal and discoid technologies: new insights from experimental and archaeological lithic series. J Archaeol Sci Rep 8:70-81. https://doi.org/10.1016/j.jasrep.2016.05.062

Polo A, Benito A, Martínez J, Mora R (2016) Formation processes and stratigraphic integrity of the Middle-to-Upper Palaeolithic sequence at Cova Gran de Santa Linya (southeastern Prepyrenees of Lleida, Iberian peninsula). Quat Int 417:16-38. https://doi.org/10.1016/j. quaint.2015.10.113

Ranhorn KL, Braun DR, Biermann Gürbüz RE, Greiner E, Wawrzyniak D, Brooks AS (2018) Evaluating prepared core assemblages with three-dimensional methods: a case study from the Middle Paleolithic at Skhūl (Israel). Archaeol Anthropol Sci:1-14. https://doi.org/10. 1007/s12520-018-0746-Z

Reeves JS, McPherron SP, Aldeias V, Dibble HL, Goldberg P, Sandgathe D, Turq A (2019) Measuring spatial structure in time-averaged deposits insights from Roc de Marsal, France. Archaeol Anthropol Sci 11(10):5743-5762. https://doi.org/10.1007/s12520-019-00871-y

Rivals F, Schulz E, Kaiser TM (2009a) A new application of dental wear analyses: estimation of duration of hominid occupation in 
archaeological localities. J Hum Evol 56:329-339. https://doi.org/ 10.1016/j.jhevol.2008.11.005

Rivals F, Moncel MH, Patou-Mathis M (2009b) Seasonality and intra-site variation of Neanderthal occupations in the Middle Palaeolithic locality of Payre (Ardèche, France) using dental wear analyses. J Archaeol Sci 36:1070-1078. https://doi.org/10.1016/j.jas.2008.12. 009

Rivals F, Julien MA, Kuiterns M, Van Kolfschoten T, Serangeli J, Drucker DG, Bocherens H, Conard NJ (2014) Investigation of equid paleodiet from Schöningen 13 II-4 through dental wear and isotopic analyses: archaeological implications. J Hum Evol 89:129-137. https://doi.org/10.1016/j.jhevol.2014.04.002

Rivals F, Prignano L, Semprebon GM, Lozano S (2015) A tool for determining duration of mortality events in archaeological assemblages using extant ungulate microwear. Sci Rep 5:17330. https:// doi.org/10.1038/srep17330

Rodríguez A, Rivals F, Saladié P, Carbonell E (2016) Season of bison mortality in TD10.2 bone bed at Gran Dolina site (Atapuerca): integrating tooth eruption, wear, and microwear methods. J Archaeol Sci Rep 6:780-789. https://doi.org/10.1016/j.jasrep.2015.11.033

Roebroeks JW (1988) From find-scatters to early hominid behaviour: a study of Middle Palaeolithic riverside settlements at MaastrichtBelvédère (the Netherlands). Universiteit Leiden, Leiden

Romagnoli F, Bargalló A, Chacón GM, Gómez B, Vaquero M (2016) Testing a hypothesis about the importance of the quality of raw material on technological changes at Abric Romaní (Capellades, Spain): some considerations using a high-resolution techno-economic perspective. J Lithic Stud 3(2):1-25. https://doi.org/10. 2218/j1s.v3i2.1443

Romagnoli F, Gómez B, Bargalló A, Chacón MG, Vaquero M (2017) Here and now or a previously planned strategy? Rethinking the concept of ramification for micro-production in expedient contexts: implications for Neanderthal socio-economic behaviour. Quat Int 474:168-181. https://doi.org/10.1016/j.quaint.2017.12.036

Romagnoli F, Nishiaki Y, Rivals F, Vaquero M (2018) Time uncertainty, site formation processes, and human behaviours: new insights on old issues in high-resolution archaeology. Quat Int 474(B):99-102. https://doi.org/10.1016/j.quaint.2018.04.033

Romagnoli F, Vaquero M (2016) Quantitative stone tools intra-site point and orientation patterns of a Middle Palaeolithic living floor: a GIS multi-scalar spatial and temporal approach. Quartär 63:47-60

Rosell J, Blasco R, Fernández MC, Vaquero M, Carbonell E (2012a) Connecting areas: faunal refits as a diagnostic element to identify synchronicity in the Abric Romaní archaeological assemblages. Quat Int 252:56-67. https://doi.org/10.1016/j.quaint.2011.02.019

Rosell J, Cáceres I, Blasco R, Bennàsar M, Bravo P, Campeny G, Esteban M, Fernández MC, Gabucio MJ, Huguet R, Ibáñez N, Martín P, Rivals F, Rodríguez A, Saladié P (2012b) A zooarchaeological contribution to establish occupational patterns at level $\mathrm{J}$ of Abric Romaní (Barcelona, Spain). Quat Int 247:69-84. https://doi.org/ 10.1016/j.quaint.2011.01.020

Rots V (2015a) Hafting and site function in the European Middle Paleolithic. In: Conard NJ, Delagnes A (eds) Settlement dynamics of the Middle Paleolithic and Middle Stone Age Iv. Kerns Verlag, Tübingen, pp 383-410

Rots V (2015b) Keys to the identification of prehension and hafting traces. In: Marreiros JM, Gibaja JF, Bicho NF (eds) Use-wear and residue analysis in archaeology. Springer Business+Media, Heidelberg, pp 83-104

Sañudo P, Blasco R, Fernández J (2016) Site formation dynamics and human occupations at Bolomor Cave (Valencia, Spain): archaeostratigraphic analysis of levels I to XII (100-200 ka). Quat Int 417:94-104. https://doi.org/10.1016/j.quaint.2015.09.044

Sañudo P, Vallverdú J, Canals A (2012) Spatial patterns in level J. In: Carbonell E (ed) High resolution archaeology and Neanderthal behavior: time and space in level J of Abric Romaní (Capellades, Spain). Springer Business+Media, Dordrecht, pp 47-76

Schoville BJ, Otárola E (2014) A model for hunter-gatherer skeletal element transport: the effect of prey body size, carriers, and distance. $\mathrm{J}$ Hum Evol 73:1-14. https://doi.org/10.1016/j.jhevol.2014.06.004

Shott MJ (1996) An exegesis of the curation concept. J Anthropol Res 52(3):259-280

Shott MJ (2008) Lower Paleolithic industries, time, and the meaning of assemblage variation. In: Holdaway S, Wandsnider L (eds) Time in archaeology: time perspectivism revisited. University of Utah Press, Salt Lake City, pp 46-60

Spagnolo V, Marciani G, Aureli D, Berna F, Boscato P, Ranaldo F, Ronchitelli AM (2016) Between hearths and volcanic ash: the SU 13 palimpsest of the Oscurusciuto rock shelter (Ginosa-southern Italy): analytical and interpretative questions. Quat Int 417:105121. https://doi.org/10.1016/j.quaint.2015.11.046

Sullivan AP (1992) Investigating the archaeological consequences of short-duration occupations. Am Antiq 57:99-115

Sumner TA, Kuman K (2014) Refitting evidence for the stratigraphic integrity of the Kudu Koppie Early to Middle Stone Age, northern Limpopo Province, South Africa. Quat Int 343:169-178. https://doi. org/10.1016/j.quaint.2014.04.017

Takakura J (2018) Lithic refitting and its implication for the integrity and duration of site occupation: the case of the late Upper Paleolithic site of Kiusu-5 in Hokkaido, northern Japan. Quat Int 474(B):156-167. https://doi.org/10.1016/j.quaint.2018.03.013

Terradillos M, Díez C, Jordá JF, Benito A, Clemente I, Marcos FJ (2017) San Quirce (Palencia, Spain): a Neanderthal open-air campsite with short-term occupation patterns. Quat Int 435(A):115-128. https:// doi.org/10.1016/j.quaint.2015.09.082

Thiébaut C, Claud E, Mourre V, Chacón MG, Asselin G, Brenet M, Paravel B (2010) Le recyclage et la réutilisation de nucléus et de bifaces au Paléolithique moyen en Europe occidentale: quelle fonction et quelle implications culturelles? Palethnol 2:3-38

Tsatskin A, Zaidner Y (2014) Geoarchaeological context of the later phases of Mousterian occupation (80-115 ka) at Nesher Ramla, Israel: soil erosion, deposition, and pedogenic processes. Quat Int 331:103-114. https://doi.org/10.1016/j.quaint.2013.10.050

Turq A, Faivre JP, Gravina B, Bourguignon L (2017) Building models of Neanderthal territories from raw material transports in the Aquitaine Basin (southwestern France). Quat Int 433(B):88-101. https://doi. org/10.1016/j.quaint.2016.02.062

Val A, Costamagno S, Discamps E, Chong S, Claud E, Deschamps M, Mourre V, Soulier MC, Thiébaut C (2017) Testing the influence of stone tool type on microscopic morphology of cut-marks: experimental approach and application to the archaeological record with a case study from the Middle Palaeolithic site of Noisetier Cave (Fréchet-Aure, Haute-Pyrénées, France). J Archaeol Sci Rep 11: 17-28. https://doi.org/10.1016/j.jasrep.2016.11.028

Vallverdú J (2013a) Estratigrafía y análisis de facies. In: García M, Zapata L (eds) Métodos y técnicas de análisis y estudio en arqueología prehistórica: de lo técnico a la reconstrucción de los grupos humanos. Euskal Herriko Unibertsitatearen Argitalpen Zerbitzua, Leioa, pp 145-178

Vallverdú J (2013b) La micromorfología de suelos. In: García M, Zapata L (eds) Métodos y técnicas de análisis y estudio en arqueología prehistórica: de lo técnico a la reconstrucción de los grupos humanos. Euskal Herriko Unibertsitatearen Argitalpen Zerbitzua, Leioa, pp 195-218

Vallverdú J, Courty MA (2012) Microstratigraphic analysis of level J deposits: a dual paleoenvironmental-paleoethnographic contribution to Paleolithic archeology at the Abric Romaní. In: Carbonell E (ed) High resolution archaeology and Neanderthal behaviour: time and space in level J of Abric Romaní (Capellades, Spain). Springer Business+Media, Dordrecht, pp 77-133 
Vaquero M (2008) The history of stones: behavioural inferences and temporal resolution of an archaeological assemblage from the Middle Palaeolithic. J Archaeol Sci 35(12):3178-3185. https://doi. org/10.1016/j.jas.2008.07.006

Vaquero M (2011) New perspectives on recycling lithic resources using refitting and spatial data. Quartär 58:113-130

Vaquero M (2012) Una cuestión de método... o tal vez no: la variabilidad de la talla discoidal en el Paleolítico medio del Abric Romaní. Mainake 33:233-250

Vaquero M (2013) Análisis micro-espacial: áreas domésticas, variabilidad funcional y patrones temporales. In: García M, Zapata L (eds) Métodos y técnicas de análisis y estudio en arqueología prehistórica: de lo técnico a la reconstrucción de los grupos humanos. Euskal Herriko Unibertsitatearen Argitalpen Zerbitzua, Leioa, pp 245-272

Vaquero M, Allué E, Vallverdú J (2012a) Conclusions: landscapes, campsites, time, and Neanderthal behavior. In: Carbonell E (ed) High resolution archaeology and Neanderthal behaviour: time and space in level J of Abric Romaní (Capellades, Spain). Springer Business+ Media, Dordrecht, pp 389-405

Vaquero M, Bargalló A, Chacón MG, Romagnoli F, Sañudo P (2015) Lithic recycling in a Middle Palaeolithic expedient context: evidence from the Abric Romaní (Capellades, Spain). Quat Int 361: 212-228. https://doi.org/10.1016/j.quaint.2014.05.055

Vaquero M, Chacón MG, García MD, Gómez B, Martínez K, Cuartero F (2012b) Time and space in the formation of lithic assemblages: the example of Abric Romaní level. J Quat Int 247:162-181. https://doi. org/10.1016/j.quaint.2010.12.015

Vaquero M, Fernández MC, Chacón MG, Romagnoli F, Rosell J, Sañudo P (2017) Moving things: comparing lithic and bone refits from a
Middle Paleolithic site. J Anthropol Archaeol 48:262-280. https:// doi.org/10.1016/j.jaa.2017.09.001

Vaquero M, Pastó I (2001) The definition of spatial units in Middle Palaeolithic sites: the hearth-related assemblages. J Archaeol Sci 28(11):1209-1220. https://doi.org/10.1006/jasc.2001.0656

Vaquero M, Romagnoli F (2018) Searching for lazy people: the significance of expedient behavior in the interpretation of Paleolithic assemblages. J Archaeol Method Theory 25(2):334-367. https://doi. org/10.1007/s10816-017-9339-x

Vidal P (2017) Firewood and hearths: Middle Palaeolithic woody taxa distribution from El Salt, stratigraphic unit Xb (eastern Iberia). Quat Int 457(1):74-84. https://doi.org/10.1016/j.quaint.2016.07.040

Wallace IJ, Shea JJ (2006) Mobility patterns and core technologies in the Middle Paleolithic of the Levant. J Archaeol Sci 33:1293-1309. https://doi.org/10.1016/j.jas.2006.01.005

Wandsnider L (2008) Time-averaged deposits and multitemporal processes in the Wyoming basin, intermontane North America: a preliminary consideration of land tenure in terms of occupation frequency and integration. In: Holdaway SJ, Wandsnider L (eds) Time in archaeology: time perspectivism revisited. University of Utah Press, Salt Lake City, pp 61-93

Zaidner Y, Grosman L (2015) Middle Paleolithic sidescrapers were resharped or recycled?: a view from Nesher Ramla, Israel. Quat Int 361:178-187. https://doi.org/10.1016/j.quaint.2014.11.037

Publisher's note Springer Nature remains neutral with regard to jurisdictional claims in published maps and institutional affiliations. 